\title{
JOACHIM ROSSIHNIUSE JA HEINRICH STAHLI PERIKOOPIDE VÕRDLUS ${ }^{1}$
}

\author{
AHTI LOHK, \\ KRISTIINA ROSS
}

\begin{abstract}
Annotatsioon. Artiklis kõrvutatakse kahte 17. sajandi alguse eestikeelset perikoobiraamatut, Joachim Rossihniuse ja Heinrich Stahli versiooni, et täpsustada kahe tõlke omavahelisi suhteid ning seotust võimaliku varasema traditsiooniga. Versioonide kõrvutus esitatakse eraldi kvantitatiivse ja kvalitatiivse analüüsina. Tulemused näitavad, et kahe versiooni näol on tõenäoliselt tegu iseseisvate tõlgetega, mille suur omavaheline sarnasus on tingitud ajastuomasest tõlkemeetodist ja vaimuliku keele juurdunud traditsioonist. Ainult üksikute perikoopide korral võib oletada ühise kirjaliku lähteversiooni olemasolu.
\end{abstract}

Võtmesõnad: eesti kirjakeele ajalugu, piiblitõlge, teksti kvantitatiivne analüüs

\section{Sissejuhatus}

Eesti kirjakeele varaseima perioodi kahe olulisima säilinud allika, Joachim Rossihniuse ja Heinrich Stahli kirikuraamatute keeleline võrdlus on uurijaid intrigeerinud juba üle saja aasta. Tegu on enam-vähem üheaegsete publikatsioonidega, millest üks esindab lõunaeesti, teine põhjaeesti kirjakeelt. Sihtkeele erinevusest hoolimata on uurijate tähelepanu pälvinud kahe autori tõlketekstide suur sarnasus kattuvates osades, s.t katekismuses ja perikoopides ning tingimisi ka kirikulauludes (viimaste lõunaeestikeelsed versioonid on Rossihniuse manuaalide ainsale säilinud eksemplarile käsikirjalisena juurde köidetud). Kahe tõlke paigutine sarnasus on ärgitanud

1 Kirjutise valmimist on toetanud Eesti Teadusagentuur grandi PRG34 „Võimusuhted ja identiteet 16.-18. sajandi eesti kirjakeeles“kaudu ja Euroopa Liit Euroopa regionaalarengu fondi kaudu (Eesti-uuringute Tippkeskus). 
uurijaid otsima sellele seletusi. Siinses käsitluses püütaksegi anda probleemi uurimislukku omapoolne panus, kasutades ära Eesti Keele Instituudis koostatud eesti piiblitõlke ajaloolise konkordantsi ${ }^{2}$ materjale, mis võimaldavad Rossihniuse ja Stahli perikoobitõlkeid senisest hõlpsamini omavahel kõrvutada. Artikli alguses selgitatakse probleemi olemust ning kirjeldatakse siinse vaatluse lähtekohti. Seejärel esitatakse eraldi kvantitatiivne ja kvalitatiivne analüüs. Kokkuvõtvalt püütakse kummagi analüüsi teel saadud tulemusi üldistada.

\section{Rossihniuse ja Stahli perikoopide problemaatikast}

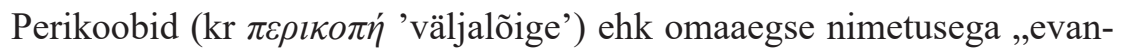
geeliumid ja epistlid“" on luteri jumalateenistusel aasta ringi pühapäeviti ja kirikupühadel ette loetavad piiblikatkendid, mis pärinevad peamiselt uuest testamendist. Iga aastaringse jumalateenistuse juurde kuulub kaks katkendit: üks on võetud uue testamendi nelja evangeeliumi seast ja seda nimetatakse evangeeliumiks, teine on võetud uue testamendi kirjade osast, Apostlite tegude raamatust või Johannese ilmutusraamatust, mõnikord ka vanast testamendist, ja seda nimetatakse epistliks. Raamatusse koondatult on perikoobid esitatud kirikuaasta järjestuses kõigepealt liikuvate pühade tsüklite kaupa alates esimesest advendist kuni kirikuaasta lõpuni ning seejärel eraldi osana pühakupäevade järgi. Iga päeva kohta tuuakse kõigepealt selle päeva epistel, seejärel evangeelium.

Luteri kiriku eripäraks võrreldes varasema katoliku kirikuga oli kogu jumalateenistuse pidamine koguduse emakeeles. Seetõttu läks perikoopide rahvakeelseid versioone vaja kohe, kui luterlikke jumalateenistusi hakati pidama. Katekismuse tõlgete kõrval olid just perikoopide ja enim lauldud kirikulaulude tekstid ilmselt need, mida hakati juba 16. sajandi esimesel poolel vahetult pärast reformatsiooni jõudmist Eesti aladele (alam)saksa keelest (s.t Martin Lutheri ülemsaksakeelse piiblitõlke alamsaksakeelse versiooni järgi) eesti keelde tõlkima. Tõenäoliselt

${ }^{2}$ Eesti piiblitõlke ajalooline konkordants (EPAK) on andmebaas, millesse on koondatud varased piiblitõlked alates Georg Mülleri jutluste piiblitsitaatidest (1600-1606) kuni 1739. aasta trükipiiblini. Andmebaasist saab materjali otsida tekstide, märksõnade, piiblisalmide ja vajaduse korral morfoloogiliste vormide kaupa. (Vt lähemalt http://www.eki.ee/piibel/.) 
levisid varased tõlked käsikirjaliste koopiatena. Meie ajani säilinud varaseimad perikoobid pärinevad ligikaudu sada aastat hiljem trükitud raamatutest.

Esimesed säilinud eestikeelsed perikoobitõlked leiduvad 1632. aastal Riias välja antud raamatus „Evangelia vnd Episteln auf alle Sonntage durchs gantze Jahr“ („Evangeeliumid ja epistlid kõigiks pühapäevadeks läbi kogu aasta"), mille tiitellehel öeldakse, et teksti on Liivimaa eesti keelde tõlkinud (In Lieffländische Estonische Sprache transferiret) Joachim Rossihnius (Rossihnius [1632] 1898: 67). Varajasimad säilinud põhjaeestikeelsed perikoobid leiduvad Heinrich Stahli kirikukäsiraamatu kolmandas osas, mis ilmus 1638. aastal Tallinnas ning kannab käsiraamatu üldpealkirja järel täpsustavat nimetust „,...] Darinnen die gewöhnliche Evangelia vnd Episteln durchs gantze Jahr“ (,... seal sees tavalised evangeeliumid ja epistlid läbi kogu aasta"). Tiitellehe järgi on raamatu saksa ja eesti keeles koostanud (In Teutscher vnd Esthnischer Sprache angefertiget) Heinrich Stahl (1638).

Heinrich Stahl on järjepidevalt olnud eesti kultuuriloos teada ja tunnustatud persoon ning kolme järgnevat põhjaeesti kirikukäsiraamatut (1654/1656, 1673/1674 ja 1693) on käsitletud tema väljaande uustrükkidena. Perikoopide tõlge tuginebki neis Stahli väljaandele. Ehkki Riias trükitud 1694/1695. aasta käsiraamatuga tekkis sellele versioonile lisaks paralleelne põhjaeesti tõlge, võib arvata, et kuni põhjaeestikeelse uue testamendi ilmumiseni (1715) olid Stahli perikoobid pidevalt kasutusel. Rossihniuse perikoope seevastu pärast esmailmumist rohkem ei trükitud, ning kuigi sajandi keskel mainib Johannes Gutslaff ([1648] 1998: 34) Rossihniust oma grammatika sissejuhatuses veel lõunaeesti kirjakeele ainsa autoriteedina, jäid tema perikoobitõlked 17. sajandi lõpukümnendil usutavasti kasutusest kõrvale. 1686. aastal ilmus peamiselt Andreas ja Adrian Virginiuse tõlgituna täiesti teist laadi lõunaeesti keeles uus testament, milles perikoobid on eraldi pealkirjastatud. Järgmised eraldi väljaandena lõunaeestikeelsed perikoobid ilmusid 1691. aastal samade autorite koostatud kirikukäsiraamatu esimese osana (Annus jt 2000: 111). Sellest peale polnud Rossihniuse perikoopide järele enam praktilist vajadust. Riia linnaraamatukogus säilinud eksemplarile tuginedes tõi Johann Heinrich Rosenplänter alles 19. sajandi alguses oma ajakirjas Rossihniuse raamatu uuesti kirjakeele ajaloo uurijate huviorbiiti (vt Rosenplänter 1816). 
Nii Rossihniuse katekismuse kui ka perikoopide korral äratab tähelepanu nende suur sarnasus vastavate Stahli avaldatud tekstidega (Stahli katekismus ilmus Rossihniuse omaga samal, 1632. aastal kirikukäsiraamatu esimese osana). Juba Villem Reiman, kes taasavaldas Rossihniuse tõlked, analüüsis eessõnas ka nende suhet Stahli tõlgetega, jõudes järeldusele, et tekstide suur sarnasus ei saa olla juhuslik, vaid nende aluseks peab olema olnud varasem ühine lähteversioon. Kuigi perikoopide osa ilmus lõunaeestikeelsena varem kui põhjaeesti keeles, pidas ta oletatavat ühist lähteteksti põhjaeestikeelseks juba ainuüksi seetõttu, et Saksamaal sündinud ja hariduse saanud Rossihniuse eesti keele ja eriti lõunaeesti keele oskus ei saanud tekstide kokkupanemise ja avaldamise aegu olla piisavalt hea. (Reiman 1898) Rossihnius ordineeriti 1622. aastal põhjaeesti keelealale Vigalasse ning ta läks sealt 1625. aastal koos Rootsi sõjaväega Tartusse, kus ta töötas järgmisest aastast alates viis aastat eesti koguduse õpetajana, siirdudes seejärel teenima teistesse lõunaeesti keeleala kogudustesse (Kingisepp jt 2002: 13). Reimani oletuse kohaselt oli Rossihnius Vigalas töötades muretsenud endale põhjaeestikeelsete tõlgete käsikirjad ning võttis need kaasa Tartusse, kus ta need, tõlketeksti pinnapealselt lõunaeestipärastades, trükis avaldamiseks ette valmistas. Reiman on Rossihniuse lõunaeesti keele oskuse suhtes üsna skeptiline ning suhtub kogu tema publitseerimistegevusse väga kriitiliselt. (Reiman 1898: XXX-XLV)

Rossihniuse ja Stahli tõlgete omavahelisi suhteid ning kummagi asendit kogu oletatavas varases tõlkeloos puudutas ühise lähteteksti hüpoteesile tuginedes ka Uku Masing oma käsitlustes „Hans Susi 1551. a. tõlkest“ ja „Somnium umbrae“ (vt Masing 1964, 1999: 135-239, 259-296). Masing lähtub veendumusest, et esimeste piiblitekstide tõlkijad pidid 16. sajandil olema emakeelsed eestlased, ning püüab, võttes aluseks säilinud hilisemad tõlked, s.t Georg Mülleri jutluste piiblitsitaadid, nn Turu käsikirja ning Rossihniuse ja Stahli väljaanded, n-ö taastada selle esmase tõlke keelelisi jooni ning rekonstrueerida arvatavate tõlkekäsikirjade saatust. Sealjuures toetub ta eituse ja objekti vormistamise võrdlusele (aga ka muudele keeleseikadele), eeldades, et algtõlkes pidi nende kasutus olema rahvakeelele lähedane. Tema rekonstruktsiooni kohaselt tuginevad Mülleri jutluste piiblitsitaadid ja Rossihniuse perikoobid mingile 16. sajandi keskpaigast pärineva algtõlke ärakirjale ning sama algupära on ka oletatavasti Pühavaimu kirikus kasutusel olnud perikoobitõlge. Eriti kehvaks 
ja moonutatuks hindab Masing (1964: 124) sealjuures Stahli versiooni, leides, et seda võiks pidada „stahlistatud Rossihniuse käsiraamatuks“.

Viimati on Stahli ja Rossihniuse keele suhteid üksikasjalikult uurinud Külli Habicht, keskendudes kahe katekismuse keelelisele võrdlusele (vt Habicht 2003). Habicht on katekismuste ühise algupära suhtes skeptiline ning hindab Rossihniuse panust kirjakeele arengusse üsna kõrgelt. Tuginedes oma uurimiskogemusele, nendib Habicht, et kõigi vana kirjakeele tekstide korral tuleb arvestada, et nende autorid kasutasid varasemaid versioone ning mugandasid neid omaenda keeleliste arusaamade kohaselt. Habichti meelest ,[a]rvamus, et Rossihnius on vaid lõunaeestipärastanud põhjaeestikeelseid tekste, mitte neid ise tõlkinud, on kaheldav, sest sellisel juhul peaksime eeldama, et ta valdas ka põhjaeesti kirikukeelt ning suutis seal välja kujunenud mõistesüsteemi küllalt sujuvalt lõunaeestilisega asendada" (Habicht 2003: 14). Kahe teksti omavahelisi suhteid vaagides jõuab Habicht (2003: 26) kokkuvõtvalt järeldusele, et nende tekstide vahel puudub otsene seos: ,Varem tõlgitud materjali kasutamist ei saa välistada kummagi autori puhul (eriti arhailine tundub tema muude tekstidega võrreldes just Stahli katekismuse keelekasutus), kuid allikate uurituse praeguses seisus pole võimalik otsestele eeskujudele viidata. [...] Sarnaselt tõlgitud tekstiosi võiks seletada pigem kirikukeele vormelite juurdumisega keelekasutuses kui samadest allikatest või teineteiselt mahakirjutamisega."

Järgnevalt püütakse jõuda selgusele, kas Rossihniuse ja Stahli perikoopide võrdlus annab alust oletada mingite ühiste lähtematerjalide olemasolu, nagu on pidanud tõenäoseks Reiman ja Masing, või saab ka perikoobitõlgete sarnasust pigem seletada juurdunud keelelise traditsiooni ja ajastuomase tõlkemeetodiga, nagu on katekismuste korral leidnud Habicht.

\section{Kvantitatiivne analüüs}

Tekstide kvantitatiivseks analüüsiks tuli eraldada EPAKist mõlema tõlke kõik ühised kirjakohad ehk piiblisalmid (edaspidi: salm), mida on 1404. (Kokku on EPAKi andmebaasis Stahli tõlke salme 1453 ja Rossihniuse tõlke salme 1579.) Ühissalmide eraldamisega ei moodustunud siiski veel ühist võrdlusalust, sest mõlemad tõlked sisaldavad salme, millest on esitatud mitu tõlkeversiooni (tähistatud $a, b$ jne): Stahli tõlkes on selliseid salme 47 ja Rossihniuse tõlkes neli. Niisugustel juhtudel valiti analüüsi vaid esimene versioon (s.t versioon a). 
Alljärgnevalt esitatud võrdlev analüüs põhineb neljal tasandil: tekstisõnade, algvormide, naabersõnade ja sõnajärje tasandil. Artikli mahu huvides ei ole analüüsiga mindud liiga detailseks. Sagedustabelid on esitatud vaid kõige sagedasemate sõnade kohta, et anda sõnadest ja tekstist kiire ülevaade. Liitsõnu käsitletakse tervikuna.

\subsection{Tekstisõnad}

Kõige üldisema mulje mõlema tõlke tekstisõnadest aitab saada nende esinemus. Siin hakkab silma Rossihniuse tõlke tekstisõnade ülekaal: Rossihniusel on tekstisõnu 30 149, Stahlil 28 437. Täpsemal uurimisel tuleb välja, et Rossihniuse tõlkesalmid on mediaankeskmise poolest ühe sõna võrra pikemad.

Ühe tõlke suurem sõnade arv ärgitab uurima, kas Rossihniuse tõlge on tekstisõnade rohkuse tõttu ka leksikaalselt mitmekesisem. Selleks arvutatakse järgmise valemi alusel leksikaalne mitmekesisus (lexical diversity või richness):

$$
\begin{aligned}
& \text { LexDiv }=\frac{\text { Unikaalsete tekstisõnade arv }}{\text { Tekstisõnade arv }} \times 100 \\
& \text { LexDiv }_{\text {Rossihnius }}=4023 / 30130 \times 100=13,4 \% \\
& \text { LexDiv }_{\text {Stahl }}=3990 / 28423 \times 100=14,0 \%
\end{aligned}
$$

Leksikaalse mitmekesisuse puhul kehtib järgmine seos: mida väiksem on leksikaalse mitmekesisuse näitaja, seda enam korratakse tekstis olevaid (unikaalseid) tekstisõnu ehk ühesuguse kirjapildiga sõnu. Sama väide on tõene ka vastupidisel juhul: mida suurem on leksikaalse mitmekesisuse näitaja, seda vähem korratakse tekstis esinevaid tekstisõnu. (Johansson, 2009) Valemi 1 kaudu arvutatud leksikaalse mitmekesisuse väärtuste alusel võib öelda, et mõlemas tõlkes on iga unikaalset tekstisõna kasutatud keskmiselt seitse korda.

Teine mõõdik, mida sõnavara uurimiseks kasutatakse, on leksikaalne tihedus (lexical density). Selle arvutamisel võetakse unikaalsete tekstisõnade asemel arvesse ainult sisusõnu ehk täistähenduslikke sõnu (content words), s.t verbe, substantiive, adjektiive ja adverbe. Viimased jäetakse sageli siiski kõrvale. (Johansson, 2009) Samamoodi on toimitud praegusel juhul. 
LexDen $=\frac{\text { Sisusõnade arv }}{\text { Tekstisõnade arv }} \times 100$

LexDen $_{\text {Rossihnius }}=12176 / 30130 \times 100=40,4 \%$

LexDen $_{\text {Stahl }}=11901 / 28423 \times 100=41,9 \%$

Sisusõnade täpsem jaotus sõnaliikide alusel on toodud tabelis 1 , kust ilmneb, et Rossihniuse tõlkes on adjektiivide osakaal mõneti suurem kui Stahli tõlkes.

Tabel 1. Rossihniuse ja Stahli sisusõnade arv ja jaotus

\begin{tabular}{|l|l|l|l|c|}
\cline { 2 - 5 } \multicolumn{1}{c|}{} & Sisusõnad & Substantiivid & Verbid & Adjektiivid \\
\hline Rossihnius & $12176(100 \%)$ & $4739(38,9 \%)$ & $6557(53,9 \%)$ & $880(7,2 \%)$ \\
\hline Stahl & $11901(100 \%)$ & $4722(39,7 \%)$ & $6392(53,7 \%)$ & $787(6,6 \%)$ \\
\hline
\end{tabular}

Valemite 1 ja 2 alusel leitud leksikaalset mitmekesisust ning tihedust näitavad mõõdikud osutavad, et Stahli ja Rossihniuse tõlketekstid ei eristu väga tugevalt üksteisest. Stahli teksti pisut suuremaid näitajaid saab seletada eelkõige sellega, et Stahlil on vähem tekstisõnu, aga erinevust võib põhjustada ka ortograafia, mis ei olnud tol perioodil veel välja kujunenud, nagu on tõdenud Habicht (2003). Seda kinnitavad ka tabelites 2 ja 3 toodud mõlema tõlke kõige äärmuslikumad näited, kus sama sõnavormi korral on kasutatud kõige enam eri sõnakujusid. Selline erinevus on tingitud kas ortograafiast või ajalooliselt erinevast tunnusmorfeemist.

Tabelite 2 ja 3 alusel Rossihniuse ja Stahli tulemusi võrreldes saab väita, et mõlemas tõlkes on kõige mitmekesisema ortograafiaga eri sõnad. Rossihniusel on erisuguse ortograafiaga sõnakujusid moodustatud 346 sõnavormist, Stahlil 355 sõnavormist.

Nagu eelnevast näha, on tekstisõnade kvantitatiivse kõrvutuse põhjal mõlema tõlke leksikaalne mitmekesisus ja tihedus küllaltki sarnased, kuid ortograafia poolest on tõlked vägagi erinevad. 
Tabel 2. Rossihniuse tõlke kõige mitmekesisema ortograafiaga sõnad

\begin{tabular}{|l|c|l|l|l|}
\hline Algvorm & $\begin{array}{c}\text { Sõna- } \\
\text { liik* }\end{array}$ & $\begin{array}{c}\text { Sõna- } \\
\text { vorm }\end{array}$ & \multicolumn{1}{|c|}{ Rossihnius } & \multicolumn{1}{|c|}{ Stahl } \\
\hline ei & D & id & ei, ey, is, isz, ej & ep \\
\hline laskma & V & ImpPrP12 & $\begin{array}{l}\text { lasckut, lascket, laskut, } \\
\text { laskcket, lasket }\end{array}$ & lascket \\
\hline ning & J & id & ninck, nink, ning, minck & ninck, nink, ningk \\
\hline jälle & D & id & jelle, jelles, ielle, ielles & jelles, jelle \\
\hline ju & D & id & io, ja, jo, joh & jo \\
\hline tema & P & PIN & $\begin{array}{l}\text { nemat, nemmat, nem- } \\
\text { met, nemmad }\end{array}$ & nemat, nemmat \\
\hline saama1 & V & IndIpfSg3 & sai, saj, sais, say & sai \\
\hline nägema & V & IndIpfSg3 & $\begin{array}{l}\text { neggi, ueggi**, näggi, } \\
\text { neggis }\end{array}$ & negki, negkis \\
\hline imetlema & V & IndIpfP13 & $\begin{array}{l}\text { immetellesit, immetellit, } \\
\text { immetelisit, immetelesit }\end{array}$ & $\begin{array}{l}\text { imetellit, imme- } \\
\text { tellit }\end{array}$ \\
\hline
\end{tabular}

* Sõnaliigi tähised: D - adverb, J - konjunktsioon, $\mathrm{P}$ - pronoomen, $\mathrm{S}$ - substantiiv, V - verb (vt http://www.filosoft.ee/html_morf_et/morfoutinfo.html).

** Sõnakuju ueggi on tekkinud ilmselt konkordantsi aluseks olnud 1898. aasta väljaande trükiveast; originaaltrükisega teksti võrreldud pole.

Tabel 3. Stahli tõlke kõige mitmekesisema ortograafiaga sõnad

\begin{tabular}{|l|c|l|l|l|}
\hline Algvorm & $\begin{array}{c}\text { Sõna- } \\
\text { liik }\end{array}$ & $\begin{array}{c}\text { Sõna- } \\
\text { vorm }\end{array}$ & \multicolumn{1}{|c|}{ Rossihnius } & \multicolumn{1}{|c|}{ Stahl } \\
\hline kui & J & id & ku, kui, kun & $\begin{array}{l}\text { ko, kude, kudt, kuhdt, } \\
\text { kut, küdt }\end{array}$ \\
\hline Kristus & P & SgG & $\begin{array}{l}\text { Christum, } \\
\text { Christumme, } \\
\text { Christusse }\end{array}$ & $\begin{array}{l}\text { Christ, Christum, } \\
\text { Christusse, Cristusse }\end{array}$ \\
\hline $\begin{array}{l}\text { luuliiku- } \\
\text { mine }\end{array}$ & S & PIN & luhlichkmisset & $\begin{array}{l}\text { luhlickmisset, } \\
\text { luhligkmisset, } \\
\text { luhlihckmisset, } \\
\text { luhlihgkmisset }\end{array}$ \\
\hline aitama & V & PtsPs & awitanut & $\begin{array}{l}\text { aitanut, aitnut, } \\
\text { awwitanut }\end{array}$ \\
\hline kes & $\mathrm{P}$ & SgAd & kell, kel & kennel, kel, kenel \\
\hline liigutama & $\mathrm{V}$ & IndIpfSg3 & lihkutis & $\begin{array}{l}\text { lihckotis, lihckotas, } \\
\text { lihckutis }\end{array}$ \\
\hline mina & $\mathrm{P}$ & IndIpfSg3 & minnu, minu & münno, mu, müno \\
\hline
\end{tabular}




\subsection{Algvormid}

Sõnavara üksikasjalikku uurimist võimaldavad tekstisõnade normaliseeritud kujud ehk praegusel juhul algvormid, millega jäävad kõrvale mõlema tõlke ortograafilised, aga ka muutevormidest tulenevad erinevused. Esmalt koostati Venni diagramm ${ }^{3}$ (vt joonis 1), mille kolmes joontega piiritletud alas olevad sõnad on esitatud nii, et kõige sagedasemad paiknevad eespool. Punktid loendite lõpus osutavad, et diagramm ei kajasta kogu sõnavara, ometi saame siit teada algvormide koguarvud, protsendid ja kummalegi tõlkele ainuomased sagedasimad sõnad, aga ka ühissõnad. Koos Venni diagrammiga on esitatud neli hulgatehet, mis on tehtud mõlema tõlke algvormidega. Seejuures tähistab R kõigi Rossihniuse tõlke (unikaalsete) algvormide hulka ja S kõigi Stahli tõlke (unikaalsete) algvormide hulka.

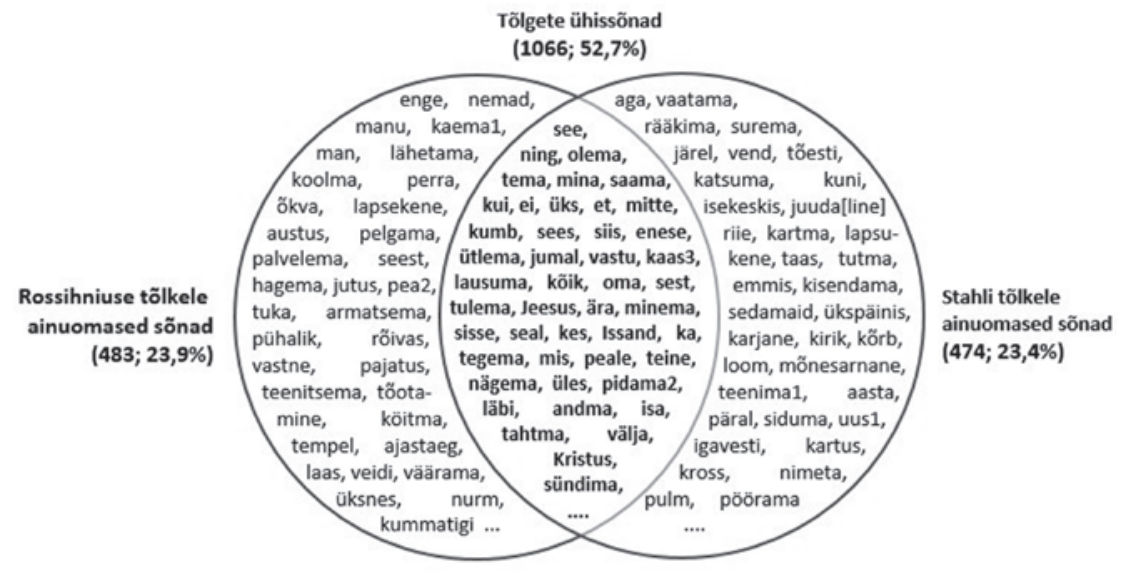

Joonis 1. Rossihniuse ja Stahli tõlke ühiste ja ainuomaste sõnade osakaalud

Uurimistulemustest ilmneb, et Rossihniuse tõlkes on 1549 ja Stahli tõlkes 1540 unikaalset algvormi. Mõlema tõlke hulkade ühendamisel moodustub hulk, milles on 2023 unikaalset algvormi. Sealjuures ühiseid sõnu on tõlgetel 1066. Rossihniuse tõlkes on unikaalseid sõnu 483 ja Stahli tõlkes 474.

3 John Venni järgi nime saanud diagramm, mida kasutatakse hulga elementide erinevuste ja sarnasuste, aga ka nende põhitehete graafiliseks kujutamiseks. 


$$
|\mathrm{R}|=1549
$$

Hulkade $S$ ja R ühend: $|\mathrm{S} \cup \mathrm{R}|=2023$

Hulkade $R$ ja $S$ vahe: $|R \backslash S|=483$

$$
|\mathrm{S}|=1540
$$

Hulkade $S$ ja R ühisosa: $|\mathrm{S} \cap \mathrm{R}|=1066$ Hulkade $S$ ja $R$ vahe: $|\mathrm{S} \backslash \mathrm{R}|=474$

Et uurida Venni diagrammi alusel tekkinud üldpilti detailsemalt, esitatakse tabelis 4 tõlketi ja sõnaliigiti sagedasimad ainuomaste sõnade algvormid. Loend sisaldab vaid selliseid sõnu, mille esinemissagedus on suurem viiest või sellega võrdne. Iga sagedusloendi ees on tõlgete võrdluseks esitatud sõnaliigi statistika. Seevastu tabelites $5-8$ on toodud tugeva seosega tõlgetevahelised sünonüümid (s.t sõnad, mis teises tõlkes on asendatud), mis aitavad näha tõlgete sõnavaralist erinevust.

Tabelist 4 ilmneb, et iga sõnaliigi puhul on tõlgete esimeste sõnade arvud (sagedus suurem viiest või sellega võrdne) üsna võrdväärsed. Näiteks on substantiivide hulgas Rossihniusel niisuguseid sõnu 26 ja Stahlil 30. Verbide puhul on vastavad arvud 19 ja 16 . Ülejäänud sõnaliikide korral on erinevus vaid kaks.

Üsna võrdväärne on ka tõlgetele ainuomaste sõnade osakaal kogu sõnaliigi sõnavarast. Näiteks on substantiivide hulgas ainuomaste sõnade osakaal Rossihniusel 34,4\% ja Stahlil 33,9\%. Verbide puhul on osakaalud vastavalt $27,0 \%$ ja $27,8 \%$. Erandiks on adjektiivid, kus Rossihniuse tõlkes on ainuomaseid unikaalseid algvorme 23 võrra rohkem. Niisugune erinevus tuleneb sellest, et terve sagedusloendi alusel on just ühe korra esinevaid sõnu Rossihniuse tõlkes ca 20 võrra rohkem. Täpsemalt, Rossihniuse tõlkes on 50 ainuomast sõna esinemissagedusega üks, Stahli tõlkes aga 31. Olgu siinkohal väikese kõrvalepõikena toodud mõned huvitavad näited ${ }^{4}$.

Rossihnius: heldemeelelik, ilmapüretatud, ilmavärvitud,jumalapelglik, jumalavallaline, kaksipidimõtlik, pikkmeelelik, pordupealne, täämbane, ondsalik.

Stahl: hiljulikmeelne, kaaskannatlik, kebjas, pöörel, teenstlik, veljeline, ägalik, ümberkondne.

Tabelis 4 annavad adjektiivid veelgi enam kõneainet. Nimelt hakkab silma, et Rossihniuse tõlkes on üheksast juhust kuus lik-lõpulised sõnad. Kõiki adjektiive uurides selgubki, et Rossihniuse tõlkes on 58 lik-lõpulist adjektiivi, mida on ligikaudu poole rohkem kui Stahli tõlkes (28). Sealjuures 20 Rossihniuse tõlke lik-lõpulist sõna esinevad ka Stahli 28 sõna hulgas.

${ }^{4}$ Liht- ja liitsõnu ei ole eraldi arvesse võetud (nagu ka analüüsis tervikuna). 
Tabel 4. Sagedasimad tõlgetele ainuomased sõnad sõnaliikide kaupa

\begin{tabular}{|c|c|c|}
\hline & Rossihnius & Stahl \\
\hline & 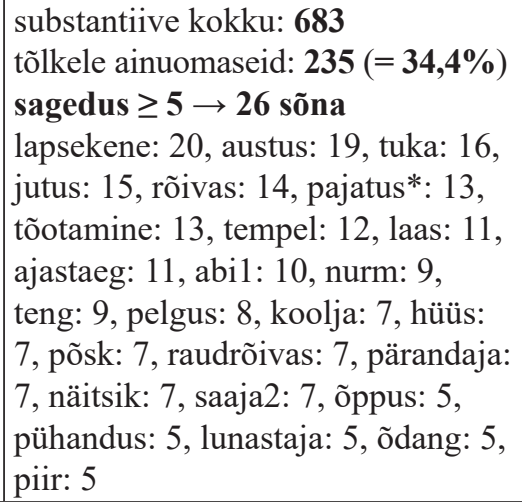 & $\begin{array}{l}\text { substantiive kokku: } \mathbf{6 9 3} \\
\text { tõlkele ainuomaseid: } \mathbf{2 3 5} \text { (=33,9\%) } \\
\text { sagedus } \geq \mathbf{5} \rightarrow \mathbf{3 0} \text { sõna } \\
\text { vend: } 32 \text {, juudaline: } 18 \text {, riie: } 16, \\
\text { lapsukene: } 16 \text {, kõrb: } 11 \text {, karjane: } \\
\text { 11, kirik: } 11 \text {, aasta: } 10 \text {, kartus: } 9 \text {, } \\
\text { loom: } 9 \text {, pulm: } 9 \text {, kross: } 9 \text {, meele- } \\
\text { vald: } 8 \text {, jutlus: } 7 \text {, ümmardaja: } 7, \\
\text { roe: } 6 \text {, kurjus: } 6 \text {, hoone: } 6 \text {, pärija: } 6 \text {, } \\
\text { tapja: } 5 \text {, kasu: } 5 \text {, nägu: } 5 \text {, tasadus: } \\
5 \text {, raudriie: } 5 \text {, põld: } 5 \text {, lugu: } 5 \text {, raja: } \\
\text { 5, alandus: } 5 \text {, ligimene: } 5 \text {, õhtu: } 5\end{array}$ \\
\hline & $\begin{array}{l}\text { verbe kokku: } \mathbf{3 0 7} \\
\text { tõlkele ainuomaseid: } \mathbf{8 3} \text { (= } \mathbf{2 7 , 0 \% )} \\
\text { sagedus } \geq \mathbf{5} \rightarrow \mathbf{1 9} \text { sõna } \\
\text { kaema: } 101 \text {, lähetama: } 36 \text {, koolma: } \\
\text { 34, pelgama: } 19 \text {, palvelema: } 18, \\
\text { hagema: } 16 \text {, armatsema: } 15, \text { tee- } \\
\text { nitsema: } 13 \text {, köitma: } 12 \text {, väärama: } \\
\text { 11, avaldama: } 9 \text {, tänitama: } 9 \text {, } \\
\text { hoolitsema: } 6 \text {, valima: } 6 \text {, tõukama: } \\
\text { 6, ohvritsema: } 5 \text {, himutsema: } 5 \text {, } \\
\text { põimama: } 5 \text {, itkema: } 5\end{array}$ & $\begin{array}{l}\text { verbe kokku: } \mathbf{3 0 9} \\
\text { tõlkele ainuomaseid: } \mathbf{8 6} \text { (= } \mathbf{2 7 , 8 \% )} \\
\text { sagedus } \geq \mathbf{5} \rightarrow \mathbf{1 6} \text { sõna } \\
\text { vaatama: } 70 \text {, rääkima: } 64 \text {, surema: } \\
\text { 46, katsuma: } 24 \text {, kartma: } 17 \text {, tutma: } \\
\text { 15, kisendama: } 11 \text {, teenima: } 11, \\
\text { siduma: } 9 \text {, pöörama: } 9 \text {, lesima: } 8, \\
\text { nõudma: } 7 \text {, lükkama: } 7 \text {, jutlema: } 6 \text {, } \\
\text { nutma: } 5 \text {, võidma: } 5\end{array}$ \\
\hline & $\begin{array}{l}\text { adjektiive kokku: } \mathbf{1 8 1} \\
\text { tõlkele ainuomaseid: } \mathbf{7 8}(=\mathbf{4 3 , 1 \% )} \\
\text { sagedus } \geq \mathbf{5} \rightarrow \mathbf{9} \text { sõna } \\
\text { vastne: } 14, \text { pühalik: } 14 \text {, tõbine: } 9 \text {, } \\
\text { sõnavõtlik: } 8 \text {, murelik: } 7 \text {, lapselik: } \\
\text { 6, inimeselik: } 5 \text {, armulik: } 5 \text {, kura: } 5 \\
\end{array}$ & $\begin{array}{l}\text { adjektiive kokku: } \mathbf{1 5 7} \\
\text { tõlkele ainuomaseid: } \mathbf{5 5}(=\mathbf{3 5 , 0} \%) \\
\text { sagedus } \geq \mathbf{5} \rightarrow \mathbf{7} \text { sõna } \\
\text { uus: } 9 \text {, mõnesarnane: } 7 \text {, nõder: } 7 \text {, } \\
\text { kurb: } 6 \text {, kuninglik: } 5 \text {, näljane: } 5 \text {, } \\
\text { paha: } 5\end{array}$ \\
\hline $\begin{array}{l}\frac{0}{2} \\
\frac{0}{2} \\
\frac{2}{2} \\
\frac{2}{4}\end{array}$ & $\begin{array}{l}\text { adverbe kokku: } 175 \text { sõna } \\
\text { tõlkele ainuomaseid: } \mathbf{6 7}(=\mathbf{3 8 , 3 \% )} \\
\text { sagedus } \geq \mathbf{5} \rightarrow \mathbf{1 0} \text { sõna } \\
\text { õkva: } 23 \text {, pea: } 16 \text {, üksnes: } 11, \\
\text { veidi: } 11 \text {, kummatigi: } 10, \text { manu: } 9 \text {, } \\
\text { esmalt: } 8 \text {, õigede: } 7 \text {, igavelt: } 7, \\
\text { lähut: } 7, \text { parhilla: } 6, \text { keskele: } 5\end{array}$ & $\begin{array}{l}\text { adverbe kokku: } \mathbf{1 7 9} \text { sõna } \\
\text { tõlkele ainuomaseid: } \mathbf{7 0} \text { (= } \mathbf{3 9 , 1 \% )} \\
\text { sagedus } \geq \mathbf{5} \rightarrow \mathbf{1 2} \text { sõna } \\
\text { tõesti: } 29 \text {, isekeskis: } 18 \text {, taas: } 16, \\
\text { ükspäinis: } 12 \text {, sedamaid: } 11 \text {, päral: } \\
\text { 10, nimeta: } 9 \text {, uuesti: } 9 \text {, igavesti: } 9 \text {, } \\
\text { pisut: } 7 \text {, õigesti: } 6 \text {, avalikult: } 5\end{array}$ \\
\hline
\end{tabular}

* pajatus esineb ka Stahlil, kuid ainult liitsõnas liikpajatus. 
Võrdluseks olgu toodud tekstis ühe korra esinevate ainuomaste sõnade esinemissagedus ka teiste sõnaliikide korral. Rossihniuse tõlkes on niisuguseid substantiive 166, verbe 49 ja adverbe 33 ning Stahli tõlkes vastavalt 144, 43 ja 38. Kui aga võtta võrdlusse mõlema tõlke ainulaadsete ja ühe korra esinevate sõnade osakaalud, ilmnevad olulised sõnaliigilised erinevused vaid adjektiivide korral.

Järgmisena väärivad tähelepanu tõlgeteülesed sünonüümid - sõnapaarid, kus ühe tõlke sõna on teises tõlkes samas kontekstis asendatud teise sarnase sõnaga. Võib ka öelda, et need on asendussõnad, mille korral ühes tõlkes esineb alati (või enamasti) üks, teises tõlkes alati (või enamasti) teine paari liige. Sealjuures ei pruugi olla tegu range sünonüümiaga. Need sõnad võivad olla ka lähisünonüümid ${ }^{5}$ (near synonym) või lausa hägusnüümid ${ }^{6}$ (fuzzynym), kuna ei ole võimalik öelda, kas neid saab ka mõnes teises kontekstis vastastikku ära vahetada nii, et teksti sisu ei muutu ${ }^{7}$, nt vihastama ja vihkama. Seega ei ole sünonüümiseos kahe sõna vahel siin alati väga range.

Tabelites 5-8 esitatud sõnapaarid on leitud poolautomaatselt. Automaatselt on koostatud kaks tabelit. Esimesel juhul on võetud sisendiks ühe tõlke kõik substantiivid, verbid, adjektiivid ja adverbid ning teisel juhul teise tõlke neidsamu sõnaliike esindavad sõnad. Kõigepealt on leitud iga sisendsõna ja selle sõnaliigi korral kõik kohad, kus see sisendsõna tõlketekstis esineb, ning saadud salmide alusel on loodud sagedusloend teise tõlke sõnadest, mis vastavad sisendsõna sõnaliigile. Et lihtsustada edasist uurimist, järjestati sagedusloend kahaneva sageduse alusel.

Näiteks on programmiväljundi reas mõnesugune $A 8 \rightarrow$ mõnesarnane: 7, üürikene: 1, kurb: 1, hea: 1, mõnesugune: 1, sarnane: 1 programmi sisend Rossihniuse tõlke sõna mõnesugune koos sõnaliigiga $A$ (adjektiiv). Programm on leidnud, et sõna mõnesugune esineb Rossihniuse tõlkes kaheksa korda. Selle tõlke asukohasalmide alusel on leitud Stahli tõlkest kõik adjektiivid ja loodud neist kahanevalt järjestatud sagedusloend. Näitest ilmneb, et teises tõlkes on esimesel kohal mõnesarnane, mis erineb sisendsõnast

\footnotetext{
5 Kognitiivselt sarnased (Inkpen jt 2007).

6 Semantiliselt seotud, kuid jääb ebaselgeks, milline semantiline seos täpselt nende vahel on või kuidas need sõnad täpsemalt semantilises võrgus suhestuvad (Pazienza jt 2008).

7 Nn vahetatavuse printsiip (interchangeability principle), mida kasutatakse reeglina, et kontrollida, kas kaks sõna sobivad sünonüümideks või ühes sünohulgas kasutamiseks (Miller 1998).
} 
mõnesugune. Seejärel saab uurida, mitu korda esineb mõnesarnane Stahli tõlkes ja mitmendal kohal on mõnesugune selle sagedusloendis. Kui mõnesarnase esinemissagedus on sarnane mõnesuguse koosesinemisega, saab selle näitena kasutusele võtta. Erandiks on juhud, kui sagedusloendi esimene sõna ei tundu olevat sisendsõnaga kognitiivselt sarnane. Sellisel juhul tuleb võrrelda ka mõlema tõlke salmide tekste, et näha, kas sõnu on tõepoolest samas kontekstis kasutatud. Keerulisim näide on sõna kaema (vt tabel 6), mille sagedasim vaste on olema, kuid järgmised kaks sagedusloendi sõna on need, mida kasutatakse asendusena (vaatama ja katsuma). Sõnu esinemis- või koosesinemissagedusega alla kolme siinkohal ei vaadelda.

Seega, tabelite 5-8 koostamisel sai seatud eesmärgiks leida võimalikult tugeva seosega sünonüümsete asendussõnade paarid. Neljast tabelist on võimalik ammutada mitmekülgseid teadmisi tõlgeteüleste asendussõnade kohta. Selgema ülevaate huvides anname iga erineva sisuga infotüki edasi järgmises loendis.

1. Iga tõlkesõna järel on antud selle sõna arv tõlketekstis. Näiteks tähendab ,veli (72)“, et sõna veli esineb Rossihniuse tõlketekstis kokku 72 korda.

2. Tabeliväli „Koosesinemine“ näitab, mitu korda esineb kaks sõna korraga samades salmides, kuid eri tõlgetes. Näiteks esinevad veli ja vend samades salmides samal ajal 32 korda.

3. Seose tugevuse protsent iga sõna järel näitab, kui suur on tõenäosus, et üks sõna ühe tõlke mingis salmis tingib teise sünonüümse asendussõna esiletuleku teise tõlke samas salmis. Ilmekat näidet pakub tabel 5: iga kord, kui Rossihniuse mingis salmis on rõivas, on samas salmis Stahli tõlkes kindlasti riie; kui aga Stahli tõlkes on sõna riie, siis $87,5 \%$ juhtudest on Rossihniuse tõlkes rõivas.

4. Kummalegi tõlkele ainuomased sõnad on tähistatud sümboliga \#. Näiteks on sõna veli omane vaid Rossihniuse tõlkele, kuid riie üksnes Stahli tõlkele.

5. Ühissõnad, millel on kalduvus olla pigem ühele tõlkele omasemad (edaspidi: ühele või teisele tõlkele eriomased sõnad), on tähistatud numbrilise ülaindeksiga. Seejuures kajastab ülaindeks sõna esinemise arvu teises tõlkes. Näiteks on seadus omasem Rossihniuse tõlkele, kuid neljal korral esineb see ka Stahli tõlkes; tõotus on omasem Stahli tõlkele, kuid kolmel korral on seda kasutatud ka Rossihniuse tõlkes. 
6. Ühissõnad, millele ei ole lisatud ühtki märget, esinevad mõlemas tõlkes võrdväärsel või sellisel hulgal, mis ei tekita kahtlust eriomasusele kalduvuse suhtes.

7. Tabeliridadel korduvad sõnad on esile toodud poolpaksu kirjaga. Ainus näide on tabelis 6 .

Tabel 5. Tõlgeteülesed asendussõnad - substantiivid

\begin{tabular}{|c|c|c|c|c|}
\hline \multicolumn{5}{|c|}{ Substantiivid } \\
\hline Rossihnius & Seose tugevus & Koosesinemine & Stahl & Seose tugevus \\
\hline veli (72) & $44.4 \%$ & 32 & vend $^{\#}(32)$ & $100.0 \%$ \\
\hline seadus $^{4}(33)$ & $87.9 \%$ & 29 & käsk $^{8}(37)$ & $78.4 \%$ \\
\hline rõivas" (14) & $100.0 \%$ & 14 & riie $^{\#}(16)$ & $87.5 \%$ \\
\hline tõotamine ${ }^{\#}(13)$ & $100.0 \%$ & 13 & tõotus ${ }^{3}(16)$ & $81.3 \%$ \\
\hline laas $^{\#}(11)$ & $100.0 \%$ & 11 & kõrb" (11) & $100.0 \%$ \\
\hline tempel ${ }^{\#}(12)$ & $91.7 \%$ & 11 & kirik $^{\#}(11)$ & $100.0 \%$ \\
\hline ajastaeg ${ }^{\#}(11)$ & $90.9 \%$ & 10 & aasta $^{\#}(10)$ & $100.0 \%$ \\
\hline tähendamine ${ }^{5}(14)$ & $71.4 \%$ & 10 & liikpajatus ${ }^{\#}(14)$ & $71.4 \%$ \\
\hline karjus $^{1}(10)$ & $90.0 \%$ & 9 & karjane $^{\#}(11)$ & $81.8 \%$ \\
\hline tuka" $(16)$ & $56.3 \%$ & 9 & ots (13) & $69.2 \%$ \\
\hline
\end{tabular}

Tabel 6. Tõlgeteülesed asendussõnad - verbid

\begin{tabular}{|c|c|c|c|c|}
\hline \multicolumn{5}{|c|}{ Verbid } \\
\hline Rossihnius & Seose tugevus & Koosesinemine & Stahl & Seose tugevus \\
\hline kaema $^{\#}(101)$ & $66.3 \%$ & 67 & vaatama" $(70)$ & $95.7 \%$ \\
\hline pajatama (77) & $77.9 \%$ & 60 & rääkima2 ${ }^{\#}(64)$ & $93.8 \%$ \\
\hline lähetama" $(36)$ & $100.0 \%$ & 36 & läkitama ${ }^{2}(36)$ & $100.0 \%$ \\
\hline koolma ${ }^{\#}(33)$ & $84.8 \%$ & 28 & surema $^{\#}(46)$ & $60.9 \%$ \\
\hline kaema $^{\#}(101)$ & $22.8 \%$ & 23 & katsuma ${ }^{\#}(24)$ & $95.8 \%$ \\
\hline tooma (33) & $54.5 \%$ & 18 & kandma ${ }^{\#}(37)$ & $48.6 \%$ \\
\hline pelgama ${ }^{\#}(19)$ & $84.2 \%$ & 16 & kartma $^{\#}(17)$ & $94.1 \%$ \\
\hline vihastama $^{3}(19)$ & $68.4 \%$ & 13 & vihkama $^{1}(17)$ & $76.5 \%$ \\
\hline teenitsema" (13) & $84.6 \%$ & 11 & teenima ${ }^{\#}(11)$ & $100.0 \%$ \\
\hline köitma" (12) & $75.0 \%$ & 9 & siduma ${ }^{\#}(9)$ & $100.0 \%$ \\
\hline
\end{tabular}


Tabel 7. Tõlgeteülesed asendussõnad - adjektiivid

\begin{tabular}{|c|c|c|c|c|}
\hline \multicolumn{5}{|c|}{ Adjektiivid } \\
\hline Rossihnius & Seose tugevus & Koosesinemine & Stahl & Seose tugevus \\
\hline vastne $^{\#}(14)$ & $64.3 \%$ & 9 & uus $^{\#}(9)$ & $100.0 \%$ \\
\hline mõnesugune ${ }^{1}(8)$ & $87.5 \%$ & 7 & mõnesarnane ${ }^{\#}(7)$ & $100.0 \%$ \\
\hline tõbine ${ }^{\#}(9)$ & $88.9 \%$ & 8 & haige (8) & $100.0 \%$ \\
\hline kange $^{1}(7)$ & $85.7 \%$ & 6 & vägev (17) & $35.3 \%$ \\
\hline murelik" (7) & $85.7 \%$ & 6 & kurb $^{\#}(6)$ & $100.0 \%$ \\
\hline kura ${ }^{\#}(5)$ & $100.0 \%$ & 5 & $\operatorname{paha}^{*}(5)$ & $100.0 \%$ \\
\hline nõrk ${ }^{\#}$ (4) & $100.0 \%$ & 4 & nõder ${ }^{\#}(7)$ & $57.1 \%$ \\
\hline ausalik $^{\#}$ (4) & $100.0 \%$ & 4 & $\operatorname{aus}^{3}(6)$ & $66.7 \%$ \\
\hline
\end{tabular}

Tabel 8. Tõlgeteülesed asendussõnad - adverbid

\begin{tabular}{|c|c|c|c|c|}
\hline \multicolumn{5}{|c|}{ Adverbid } \\
\hline Rossihnius & Seose tugevus & Koosesinemine & Stahl & Seose tugevus \\
\hline tõdelikult ${ }^{3}$ (33) & $84.8 \%$ & 28 & tõesti" (29) & $96.6 \%$ \\
\hline pea ${ }^{\#}(16)$ & $56.3 \%$ & 9 & sedamaid" (11) & $81.8 \%$ \\
\hline veidi $^{\#}(11)$ & $63.6 \%$ & 7 & pisut $^{\#}(7)$ & $100.0 \%$ \\
\hline üksnes" ${ }^{\#}$ (11) & $81.8 \%$ & 9 & ükspäinis" (12) & $75.0 \%$ \\
\hline igavelt" (7) & $85.7 \%$ & 6 & igavestit $^{\#}(9)$ & $66.7 \%$ \\
\hline $\operatorname{vaja}^{4}(7)$ & $57.1 \%$ & 4 & tarvis (7) & $57.1 \%$ \\
\hline õigede $^{\#}(7)$ & $71.4 \%$ & 5 & õigesti" (6) & $83.3 \%$ \\
\hline täämba ${ }^{\#}(3)$ & $100.0 \%$ & 3 & täna” (3) & $100.0 \%$ \\
\hline
\end{tabular}

Nagu tabelitest 5-8 näha, kuuluvad võimalikult tugeva seosega sünonüümsete asendussõnade hulka enamasti sõnad, mis on konkreetsele tõlkele ainuomased (tunnus \#), välja arvatud mõned numbrilise ülaindeksiga tähistatud eriomased sõnad (nt seadus, karjus, vihastama, läkitama) ja mõlemas tõlkes üldkasutatavad sõnad (kogu loend: pajatama, haige, vägev ja tarvis). Samuti ei teki vaatlusaluste tabelite põhjal kahtlust, et vastastikku asendatavaid sünonüümseid sõnu kasutatakse üsna samas tähenduses. Erandiks näib olevat tabelis 6 leiduv sõna kaema, mille vastetena esinevad sõnad vaatama ja katsuma. Seda saab aga seletada sõna katsuma varasema tähendusega 'vaatama'. 
Kokkuvõttes võib algvormide statistilise vaatluse põhjal väita, et Rossihniuse ja Stahli tekstid sarnanevad üksteisega sõnavara mahu poolest: Rossihniusel on 1549 sõna, Stahlil 1540 sõna. Sarnased on need sellegi poolest, et nende sõnavara ühendamisel (vt joonis 1) jäävad mõlema tõlke ainuomased sõnad tasakaalukalt vahemikku 23-24\%. Tõlgete sarnasus ilmneb ka selles, et substantiividest, verbidest ja adverbidest ainuomaste sõnade osakaalud konkreetse sõnaliigi korral on pea ühesugused, nt substantiividel 34,4\% ja 33,9\% (vt tabel 4). Tabelite 5-8 põhjal seisneb sarnasus selleski, et mõlemas tõlkes kasutatakse sünonüümsete asendussõnadena võrdväärsel hulgal tõlkele ainuomaseid sõnu.

Kõige silmatorkavam, aga siiski mitte väga suur erinevus on seotud adjektiividega. Rossihniuse tõlke sõnavara on adjektiivide poolest 24 sõna võrra suurem (vt tabel 4). Samuti on selles tõlkes ligikaudu 20 ainulaadset adjektiivi, mis esinevad tekstis korra. See aga on peamine põhjus, miks Rossihniusel on ainuomaste sõnade osakaal kogu adjektiivide hulgast ligikaudu 7\% suurem kui Stahlil.

\subsection{Naabersõnad ehk bigrammid}

Selles jaotises uuritakse koos esinema kalduvaid sõnapaare ehk kollokatsioone algvormide tasandil. Koosesinevate paaridena vaadeldakse siinkohal ainult bigramme, see tähendab sõnu, mis esinevad tekstis kõrvuti. Põhimõtteliselt võiks leida koosesinevate sõnade paare igast salmitekstist ka nii, et sõnapaari moodustavad salmi esimene ja viimane sõna, kuid sel viisil võivad tulemustesse sattuda sõnapaarid, mis sisuliselt ei kuulugi kokku.

Alljärgnevalt on esitatud ülevaade sõnaliigi filtri alusel sagedasti koos esinevatest sõnapaaridest ja sümmeetriliste statistikute alusel koos esinema kalduvatest sõnapaaridest.

\subsubsection{Sõnaliigi filtri alusel sagedasti koos esinevad sõnapaarid}

Triviaalseim viis tekstis esinevate sõnapaaride kohta midagi teada saada on eraldada bigrammid tekstist ja järjestada need sageduse alusel. Toetudes inglise keele põhjal tehtud uuringule, on aga Christopher Manning ja Hinrich Schütze (1999) näidanud, et sel viisil satuvad kõige suurema sageduse alusel etteotsa paarid, mis koosnevad täielikult või osaliselt funktsionaalsetest sõnadest, praegusel juhul nt ning see, olema tema, 


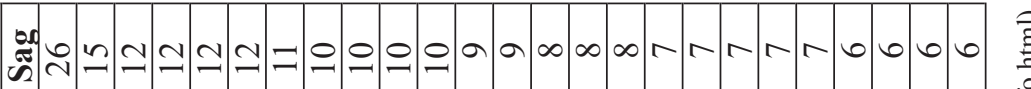

2

خి

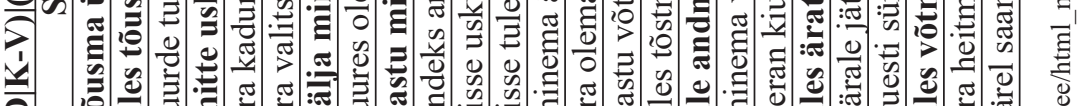

అ

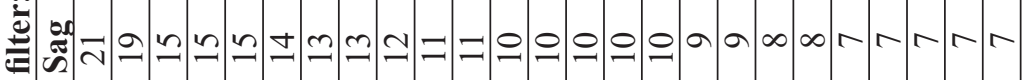

ax

ชี่

:

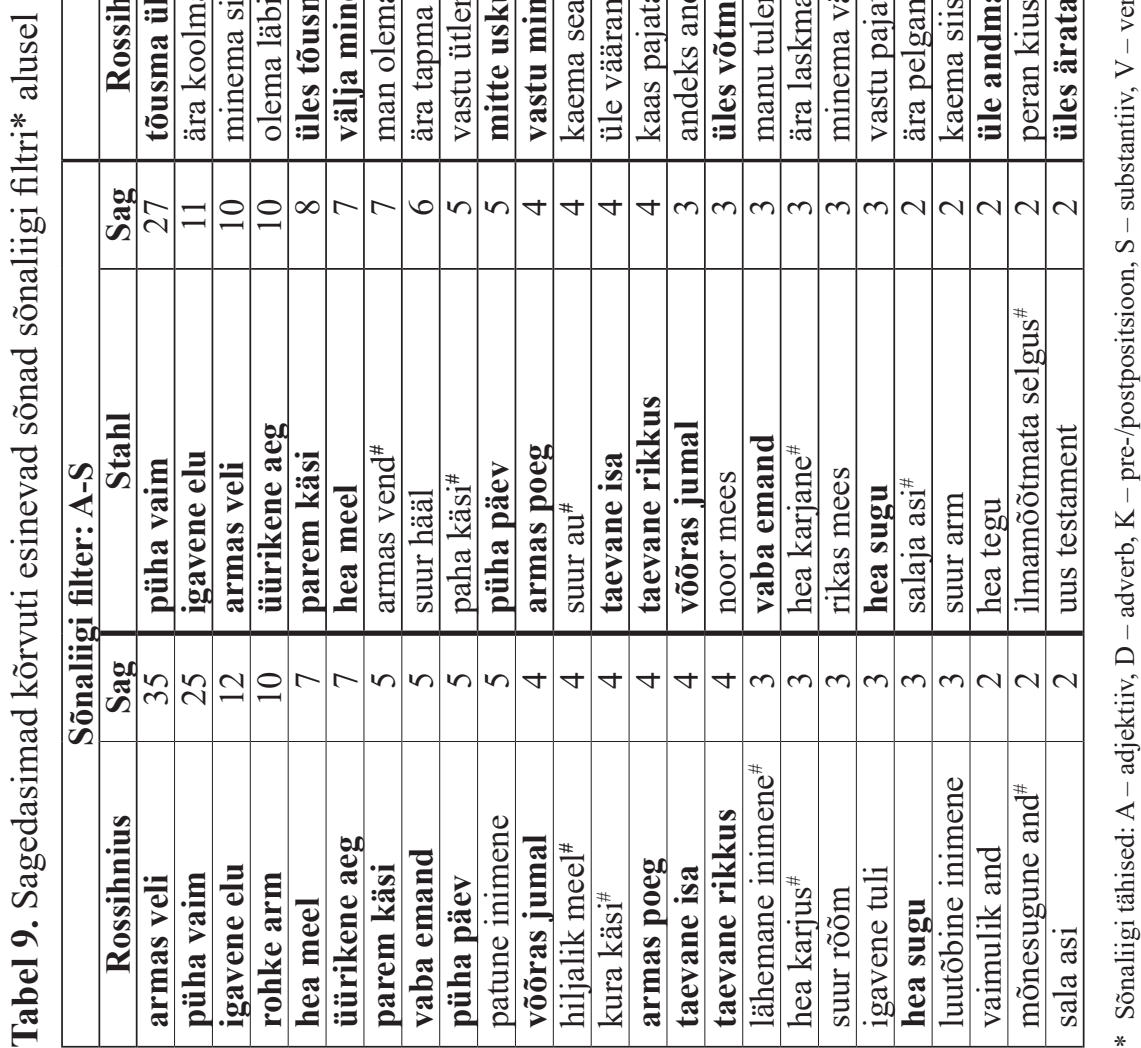


kui tema. Sellised väheütlevad paarid ei anna keeleteadlasele palju uut teadmist. Teine võte, mida Manning ja Schütze rakendavad, on sõnaliigi filtrid, mille korral eraldatakse kõige sagedasemate bigrammide hulgast vaid kindlasse sõnaliiki kuuluvate sõnade paarid, nt adjektiivi-substantiivi paarid (nt armas vend) või adverbi-verbi paarid (nt üles tõusma). Selliseid sõnapaare tõlketi kõrvutades (vt tabel 9, tunnus ${ }^{\#}$ ) on näha selgemalt, mis erinevusi tõlgete vahel esineb.

Tabeli esimene pool kuulub adjektiivi-substantiivi paaridele (sõnaliigi filter: A-S). Aluseks on võetud kõige sagedasemad sõnapaarid, mille on programm paaride kahaneva sageduse alusel väljastanud. Tabeli teise poolde on koondatud sõnapaarid, mille üks liige on verb ja teine liige adverb või pre-/postpositsioon (sõnaliigi filter: (D $\mid K-V) \mid(V-D \mid K)$ ). Siit on kõige sagedasemad (nt ei olema, saama mitte) ja muud väheütlevad paarid käsitsi eemaldatud. Selliste põhimõtete alusel loodud tabel 9 näitab, kui suur osa tõlkele ainuomaseid paare sagedasemate paaride hulgas esineb ning mis paarid on tõlgetes ühised (poolpaksus kirjas).

Tabelist nähtub, et sõnaliigi filtri A-S korral ei ole esimese kuue bigrammi hulgas ainuomaseid paare. Samal ajal on need esimesed kuus mõlemas tõlkes ühised ning jäävad tabeli etteotsa. Seevastu tabeli teise filtri $(\mathrm{D} \mid \mathrm{K}-\mathrm{V}) \mid(\mathrm{V}-\mathrm{D} \mid \mathrm{K})$ korral tuleb esile selge erinevus: Rossihniusel on tema tõlkele ainuomaseid bigramme oluliselt rohkem kui Stahlil (vastavalt 9 ja 4).

\subsubsection{Sümmeetriliste statistikute alusel koos esinema kalduvad sõnapaarid}

Sõnaliigi filtri rakendamine on sobiv viis siis, kui soovitakse teada saada, mis sõnad on sagedamini koos, kuid see ei anna hinnangut sõnade kohta, millel on n-ö vastastikune tõmme või kalduvus koos esineda. Kuigi keelestatistikas on naabersõnade seose tugevuse mõõdikutena kasutusel mitmesugused statistikud, piirdutakse siin kolme üldtuntud statistikuga: vastastikuse informatsiooni väärtuse (mutual information), t-skoori $(\text { t-score })^{8}$ ja log-tõepäraga (log-likelihood). Neid statistikuid nimetatakse sümmeetrilisteks, kuna siin ei eristata, kumb sõna sõnapaaris võib suurema tõenäosusega esineda teise sõnaga koos. Põhjaliku ülevaate kollokatsioonide tuvastamise statistikutest ja nende arvutuseeskirjad on esitanud Stefan Evert (2009) ja Stefan Th. Gries (2013).

8 t-score $=\mathrm{T}$-test. 
Tabel 10 sisaldab naabersõnu, mis on saadud eelnimetatud kolme statistiku alusel. Sõnapaarid on järjestatud kahanevalt (tugevam seos eespool), samuti on leitud igale paarile kolme statistiku pingereas keskmine positsioon. Selline lähenemisviis võimaldas saada tulemitabelisse naabersõnad, mis on kolme statistiku järgi võimalikult kõrgel positsioonil, ilma et üht statistikut oleks teisele eelistatud.

Allesitatud tabeli esimesse poolde on koondatud 25 kõige tugevama seosega adjektiivi-substantiivi (A-S) paari ja teise poolde adverbi-, pre-/ postpostiooni-verbi paari $((\mathrm{D} \mid \mathrm{K}-\mathrm{V}) \mid(\mathrm{V}-\mathrm{D} \mid \mathrm{K}))$, seejuures tähistab tunnus \# tõlkele ainuomaseid paare ja poolpaks kiri sõnu, mis esinevad ka teise tõlke materjalis. Tähelepanuväärne on, et sageduse alusel leitud bigrammid (vrd tabel 9) ei andnud nii palju tõlkele ainuomaseid naabersõnu kui statistikud. Nii on sõnaliigi filtri A-S korral üle 70\% mõlema tõlke paaridest ainuomased (täpsemalt Rossihniuse tekstis $19 / 25 \times 100=76 \%$, Stahli tekstis $18 / 25 \times 100=72 \%$ ). Teine sõnaliigi filter annab vastavateks osakaaludeks samuti kõrged $76 \%$ ja $88 \%$.

Tabelis 10 näidatud kollokatsioone iseloomustab see, et nad esinevad tekstis vaid ühe korra. Erandid on väikene uskuja, panema tallele, otsima usinasti ja üle varjama, mille sagedus on kaks, ning üle võitma, mille sagedus on kolm. Et eristada neid teistest paaridest, on need tabelis alla joonitud.

Niisiis näitab naabersõnade analüüs, et a) esinemissageduse alusel eraldatud naabersõnad sisaldavad vähem tõlkele ainuomaseid sõnapaare ja rohkem ühiseid sõnapaare ning b) statistikute alusel eraldatud naabersõnade hulgas on lausa $72-88 \%$ tõlkele ainuomaseid sõnapaare ja ainult üksikud ühissõnapaarid. Teades, et esimene lähenemisviis andis tulemuseks tihti koos esinevad naabersõnad ja teine lähenemisviis vaid korra või (harva) kaks korda tekstis esinevad naabersõnad (vt tabelid 9 ja 10), on loomulik järeldada, et esimesel juhul tulevad esile piiblis sagedamini kasutatavad paarid, teisel juhul harvem kasutatavad paarid.

\subsection{Tõlkesalmide kõrvutamine}

Nii nagu eespool, võib ka tõlkesalmide kõrvutamisel vaadata tekste kas tekstisõnade või algvormide tasandil. Salmide võrdlemist alustatakse äärmuslike näidetega ja seejärel liigutakse n-ö üldisema pildi poole, kasutades kahte mõõdikut, mida tutvustatakse järgmistes alaosades. 
Tekstide võrdlusest ilmneb, et 1404 salmist vaid ühe korral langevad kaks tõlget $100 \%$ kokku (näide $1^{9}$ ). Kõik ülejäänud 1403 salmi on tõlketi erinevad. Sarnasuse alusel teisel kohal olev salm on toodud näitena 2.

(1) Mt 16:16

R: Sihs kostis Simon Petrus, ninck laus: Sinna ollet Christus, se ellawa Jummala Poick.

S: Sihs kostis Simon Petrus / ninck laus: Sinna ollet Christus / se ellawa Jummala poick.

(2) $\operatorname{Lk} 24: 45$

R: Sihs awas temma neile ülles se moistusse, et nemmat se kirja moistsit,

S: Sihs awwas temma neile ülles moistusse / eth nemmat se kirja moistsit /

Teise äärmusse jäävad salmid, mis ei lange tõlketi mitte üheski tekstisõnas kokku. Selliseid nullsarnasusega salme on kuus ${ }^{10}$ (näide 3).

(3) $\mathrm{Rm} 12: 13$

R: Tulcket abbi neine pöhalikude waisusselle. Wötket hähl mehlel maja.

S: Awwitaket needt pöhat heddalisset. Wotket hehl meelel needt tekeijat wasto.

Järgnevalt on toodud sama tüüpi näiteid ka algvormide tasandil esitatud salmide kohta. Siin on tõlketi kokkulangevaid salme lausa 18. Üks lühematest salmidest (koos mõlema tekstitasandil tõlkega) on esitatud näitena 4.

(4) Jh $3: 6$

mis liha sündima saama see olema liha ning mis vaim sündima saama see olema vaim

R: mea lihast sündinut sahb, se om liha, ninck mea waimust sündinut sahb, se om waim.

S: Mea leehast sünditut sahp / se on leeha / ninck mea waimust sünditut sahp / se on waim.

Algvormide tasandil täielikult lahknevaid salme ei esine. Kahe tõlke kõige lahknevamaid salme esindavad näited 5 ja 6 (kokkulangevad sõnad on poolpaksus kirjas).

9 Siin ja edaspidi: R - Rossihnius, S - Stahl.

${ }^{10}$ Mt 24:16, Mt 24:20, Ap 12:2, Rm 12:13, Ef 4:5, 1Pt 3:15. 


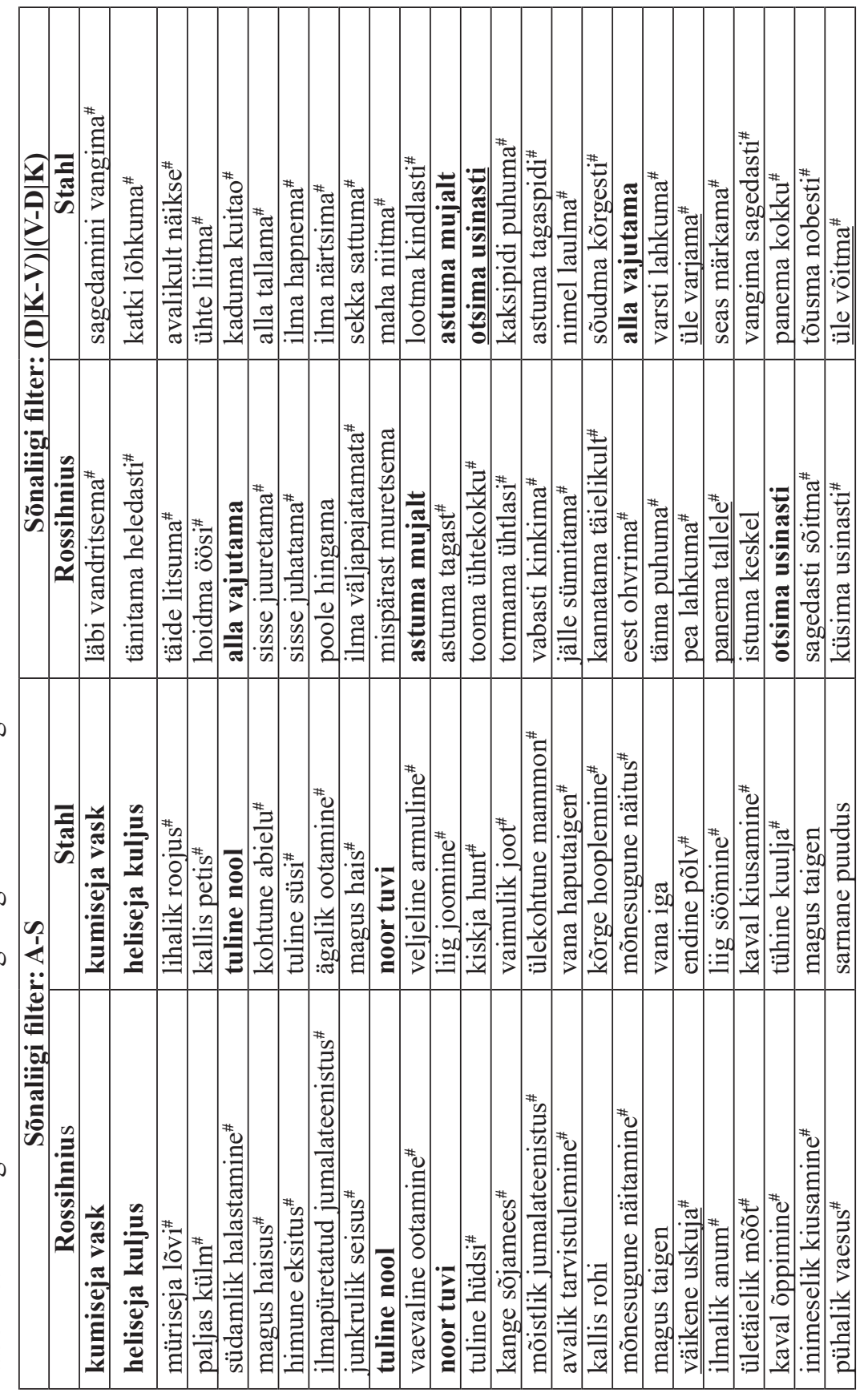


(5) 1 Pt 4:9

$\mathbf{R}$ : olema maja võtja teine teine seas ilma nurisema

R: Olcket maja wötjat teine teise sean ilmanürrisematta,

S: andma rohkesti see võõras ilma murisemine

S: Andket rochkest neile wöhral ilma murrisemisse.

(6) $\mathrm{Rm} 8: 38$

R: sest mina olema kinnitama et see surm ning elu ehk ingel ning valitsemine ehk vägi ehk mis silm ees olema ehk mis tulevalik olema

R: Sest minna olle kinnitut, et se surm ninck ello, ächk Engel ninck wallitzemine, ächk weggi, ächk mea silmade ehn om, ächk mea tullewelick om,

S: sest mina lootma kindlasti et ei surm ei elu ei ingel ei kuninglik rikkus ning vägi ei mis sündima ehk veel sündima saama

S: Sest minna lotan kindlast / eth ep surm / ep ello / ep Engel / ep Kunniglick rickus / ninck wegki / ep mea sündip / echk weel sündima sahp /

Et saada parem ülevaade kahe tõlketeksti sarnasusest või erinevusest, on alljärgnevalt kasutatud kaht mõõdikut: koosinussarnasust ja normaliseeritud pikimat ühisalamjada.

\subsubsection{Koosinussarnasus (KS)}

Üks levinuim tekstide sarnasuse mõõtmise vahend on koosinussarnasuse mõõdik, mis muu hulgas on kasutusel nii tekstiotsingu tulemuste relevantsuse hindamisel kui ka dokumentide klasterdamisel ehk rühmitamisel (Huang 2008; Gomaa, Fahmy 2013). Matemaatiliselt mõõdab see mõõdik nurga koosinust kahe vektori vahel (vt valem 3), mis on projekteeritud mitmemõõtmelises ruumis. Mitmemõõtmelise ruumi iga dimensiooni vektorile vastab unikaalne sõna (salmis). Vektori pikkus vektorruumi mudelis on määratud sõna esinemissagedusega. KSi väärtus on üks (või 100\%), kui kahe võrreldava teksti sõnad langevad (koos esinemissagedustega) kokku, ja null, kui ükski sõna kahes tekstis ei lange kokku, arvestamata sealjuures sõnade järjekorda.

Kui $R$ on Rossihniuse tõlkesalm ja $S$ Stahli tõlkesalm ning $n$ mõlema tõlkesalmi unikaalsete algvormide koguarv, siis võib KSi arvutuseeskirja esitada järgmisel viisil:

$$
\operatorname{Cos} \operatorname{Sim}(\mathbf{R}, \mathbf{S})=\cos (\theta)=\frac{\sum_{i=1}^{n} R_{i} \times S_{i}}{\sqrt{\sum_{i=1}^{n} R_{i}^{2}} \times \sqrt{\sum_{i=1}^{n} S_{i}^{2}}}
$$


Valemi 3 puhul korrutatakse lugejas mõlema tõlkesalmi samade sõnade sagedused ja liidetakse need kokku. Kui ühes salmis on sõna, mida teises ei ole, siis arvestatakse korrutamisel sagedusega 0 (null). Nimetajasse võetakse mõlema tõlkesalmi iga sõna esinemissageduse ruutude summast ruutjuur ja korrutatakse juurte väärtused omavahel.

Alljärgnevalt on kõige lühema salmi (Mt 22:38) näitel esitatud, kuidas leida KS väärtuse algvormidena antud tõlkesalmi variantide vahel.

(7)

R: see olema see ülem ning suur käsk

(Se on se üllemb ninck suhremb kesck.)

S: see olema see suur käsk

(Se om se suhremb kesck,)

Kõigepealt tuleb luua tabel, kus on esitatud mõlema tõlke kõik sõnad ja kuhu on koondatud mõlema tõlke kohta iga sõna sagedus. Seejärel tehakse valemi abil arvutus.

\begin{tabular}{|c|c|c|c|}
\hline Jrk & Sõnad & Rossihnius & Stahl \\
\hline 1 & see & 2 & 2 \\
\hline 2 & olema & 1 & 1 \\
\hline 3 & suur & 1 & 1 \\
\hline 4 & käsk & 1 & 1 \\
\hline 5 & ülem & 1 & 0 \\
\hline $\mathrm{n}$ & ning & 1 & 0 \\
\hline
\end{tabular}

$\operatorname{CosSim}(\mathbf{R}, \mathbf{S})=\frac{2 \times 2+1 \times 1+1 \times 1+1 \times 1+1 \times 0+1 \times 0}{\sqrt{2^{2}+1^{2}+1^{2}+1^{2}+1^{2}+1^{2}} \times \sqrt{2^{2}+1^{2}+1^{2}+1^{2}+0^{2}+0^{2}}}=0,881$

KS aitab näha, kui sarnased on tekstid sõnavara poolest, kuid ei ütle midagi sõnade järjekorra ega kasutatud sõnavormide kohta. See tähendab, et kui võtta kahe tõlkesalmi võrdluse aluseks algvormid, milles on täpselt samad sõnad täpselt sama esinemissagedusega, kuid eri järjekorras, on koosinussarnasus ikkagi üks. Samuti on see üks siis, kui ühes tõlkes on kasutatud näiteks lihtmineviku, teises oleviku vormi. Kui aga rakendada KSi tekstisõnadele ja algvormidele eraldi (vt joonis 2), on võimalik saada kahe teksti sarnasuse kohta lisateavet. 


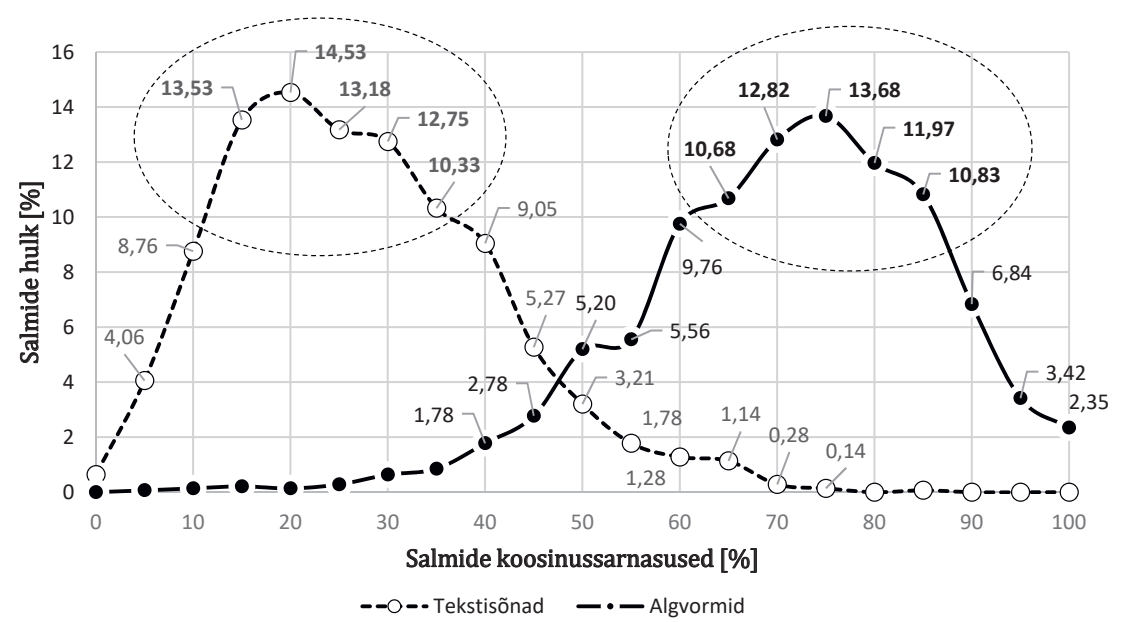

Joonis 2. Rossihniuse ja Stahli tõlkesalmide koosinussarnasuste jaotus

Jooniselt 2 võib välja lugeda, et tekstisõnade tasandil on 64,32\% (summa punktiirjoonega ala arvudest, viis suurimat) salmidest koosinussarnasusega 15-35\%, samal ajal kui algvormide tasandil langeb sarnane hulk salme $(59,98 \%)$ koosinussarnasuse vahemikku $65-85 \%$. Sellise erinevuse põhjuseid saab olla vaid kaks: tõlked erinevad ortograafia poolest tugevasti ja lausetes kasutatavad sõnavormid on väga erinevad.

\subsubsection{Normaliseeritud pikim ühisalamjada (NPÜAJ)}

KSi alternatiiv ja mõneti edasiarendatud viis on rakendada kahele tekstile (praegusel juhul tõlkesalmile) normaliseeritud pikima ühisalamjada (normalized longest common subsequence) mõõdikut. Siin ei piisa suurima väärtuse ehk ühe saamiseks sellest, et kaks teksti sisaldavad täpselt samu sõnu täpselt sama esinemissagedusega, vaid oluline on ka sõnade järjekord. Näitaja väiksem väärtus ei pruugi tulla mitte sellest, et ühest tekstist on üks sõna puudu, vaid ka sellest, et tõlkesalmide sõnadel on erinev järjekord. Näitena NPÜAJ arvutamise kohta on alljärgnevalt kasutatud tuttavat tekstikohta Mt 22:38 (vt näide 7).

Esmalt tuleb arvutada pikim ühisalamjada. Selleks püütakse järjestikku (vasakult paremale) igale Stahli salmi sõnale leida vaste Rossihniuse sõnade hulgast (samuti vasakult paremale), arvestades kitsendusega, et 
enne leitud ehk Rossihniuse teksti sõnast ei tohi hiljem leitud ehk Stahli teksti sõna eespool asuda. Kõik sõnad, millele sellisel viisil vaste leitakse, moodustavadki jada, mida nimetatakse ühisalamjadaks. Et veenduda, kas tegu on pikima ühisalamjadaga, tuleb sama protsess läbi teha ka vastupidi, s.t Rossihniuse teksti sõnadele tuleb püüda leida vasteid Stahli tekstist. Kahest ühisalamjadast pikimat nimetataksegi pikimaks ühisalamjadaks. Siinse näite puhul oleks see jada see olema see suur käsk, mis langeb täpselt kokku Stahli tekstiga. Kui ülemjada on leitud, tuleb tulemteksti normaliseerimiseks jagada selle sõnade arv kõige lühema teksti sõnade arvuga, praegusel juhul $5 / 5=1$. Siinne näide on ilmekas selle poolest, et kuigi tulemuseks tuli üks, ei olnud kaks salmiteksti teineteisega identsed.

\subsubsection{Erinevused sõnajärjes}

Eelkirjeldatud tulemust arvestades on mõistlik kasutada NPÜAJ väärtust koos koosinussarnasuse väärtusega: kui mõlema väärtus on üks, saab väita, et tekstid on $1: 1$ identsed. Kui koosinussarnasus on väiksem ühest, on oodata, et üks salm sisaldab rohkem sõnu kui teine. Selliseid salme, mis on identsed, s.t KS ja NPÜAJ võrduvad ühega, on 18, ja selliseid salme, kus NPÜAJ on üks, kuid KS on ühest väiksem, on samuti 18 (vt allolev tabel).

\begin{tabular}{|c|c|c|l|}
\hline KS & NPÜAJ & Arv & \multicolumn{1}{|c|}{ Kommentaar } \\
\hline 1 & 1 & 18 & Identsed salmid \\
\hline $\mathbf{1}$ & $<\mathbf{1}$ & $\mathbf{7}$ & Samad sõnad, eri järjekord \\
\hline$<1$ & 1 & 18 & Ühes salmis on rohkem sõnu \\
\hline
\end{tabular}

Kuna eesmärk on tuvastada salmid, mille sõnade järjekord on tõlketi erinev, võetakse alljärgnevalt lähema vaatluse alla salmid, kus KS on üks, kuid NPÜAJ on väiksem ühest, lootes nende näidete alusel leida üles kõige puhtamad erisuse juhud. Nagu näha eeltoodud tabelist, on selliseid juhte vaid seitse, mis moodustavad ligikaudu $0,5 \%$ kõigist lausetest.

Seitsmest juhust, mille korral KS on üks, kuid NPÜAJ on ühest väiksem, on kolm niisugused, kus kahes tõlkes on kõrvuti asetsevad verbid eri järjekorras (näide 8; KS = 1, NPÜAJ = 0,889). 
(8) $1 \mathrm{Kr} 15: 5$

R: ning et tema olema nägema Keefas* pärast see kaksteistkümmend

R: Ninck et temma om nettut Cephassest, perrast neist katzteistkümnes.

S: ning et tema nägema olema Keefas* pärast see kaksteistkümmend

S: Ninck eth temma nechtut on Sephast / perrast neist kaxtöistkümnest.

Kaks näidet on niisugused, kus kahes tõlkes on kõrvuti asetsevad substantiivid eri järjekorras (näide 9; KS = 1, NPÜAJ =0,900). Ülejäänud kaks näidet näivad olevat juhuslikumat laadi ja neid eraldi ei käsitleta.

(9) $\mathrm{Rm} 8: 14$

R: sest kumb see vaim jumal ajama see olema jumal laps

R: Sest kumbat se Waim Iummalast ajab, need ommat Iummala latzet,

S: sest kumb see jumal vaim ajama see olema jumal laps

S: Sest kumbat se Jummala waim hajap / needt ommat Jummala lapset.

Vaadeldud näidete alusel saab kokkuvõtvalt öelda, et salmides esineb eri järjekorraga sõnapaare. Järgmises etapis tulebki otsida välja kõik juhud, kus kõrvuti olevad naabersõnad on kahes tõlkes eri järjekorras, vältides samal ajal nelja erijuhtu.

1. Sõnapaari esimene või teine liige esineb vahetult enne või pärast sõnapaari.

... kes see juures olema kumb olema Kristus ...

... ning tema küsima tema kui palju olema sina leib tema kostma seitse ...

2. Sidesõna ümbritsevad sõnad on eri järjekorras.

... Joosep ning Maarja ...

... Maarja ning Joosep ...

3. Sõnapaar on samas kontekstis sama, aga lause lõpupoole vahetatud järjekorraga (rakendub kitsendus, mille kohaselt vahetuses olevate sõnade paarid saavad asuda teineteisest vaid kuni nelja sõna kaugusel).

ning saama tema ette kõik rahvas ühte hagema saama ning tema saama tema teine ...

ning saama tema ette kõik ilm maa rahvas koguma saama ning tema saama tema teine ...

4. Kasutatakse sünonüümseid sõnu.

pärast lausuma tema see teine vastu sina enge kui palju olema sina võlgu tema lausuma ...

pärast pajatama tema see teine vastu sina aga kui palju olema sina võlgu tema lausuma ... 
Eelmainitud nelja kitsendust rakendati 1404 tõlkesalmipaaril. Analüüsi tulemusena selgus, et 264 sõnapaari on 240 tõlkesalmis vastupidises järjekorras. Seevastu sõnapaare, mis on eri tõlgete samades salmides sama järjekorraga, on 13789 ja neid leidub kõigis salmides ehk 1404 salmis. Kuigi vastupidise järjekorraga sõnapaare on koguhulgaga võrreldes üsna vähe $(264 / 13789 \times 100=1,9 \%)$, hakkavad siin sellegipoolest silma teatud mustrid, millel peatume peale kokkuvõtvaid tabeleid ja näiteid lähemalt.

Tabel 11. Vahetatud järjekorraga sõnapaarid sõnaliigilise mustri alusel

\begin{tabular}{|c|c|c|}
\hline $\begin{array}{c}\text { Sõnaliik- } \\
\text { sõnaliik* }\end{array}$ & $\begin{array}{c}\text { Sage- } \\
\text { dus }\end{array}$ & \multicolumn{1}{|c|}{ Tõlketi vahetuses olevate sõnade paarid } \\
\hline V-V & 44 & $\begin{array}{l}\text { andma olema, arvama laskma, elama tahtma, jagama } \\
\text { olema, kiitma pidama, kiitma tahtma, nägema pidama, } \\
\text { olema kutsuma, olema kuulma, olema käima, olema } \\
\text { nägema, olema palkama, olema saama, olema tegema, } \\
\text { pidama kannatama, pidama saama, saama arvama, saama } \\
\text { maksma, saama paluma, saama ristima, saama ülendama, } \\
\text { saama ütlema, seisma võima, sööma laskma, sündima } \\
\text { pidama, tahtma arvama, tahtma küsima, tegema olema, } \\
\text { tegema pidama, tegema tahtma, tulema pidama, tulema } \\
\text { saama, tundma olema, võima mõistma, ütlema saama }\end{array}$ \\
\hline P-P & 45 & $\begin{array}{l}\text { enese ise, keegi sina, kõik see, mis see, see kumb, see } \\
\text { kõik, see sina, see üks, sina enese, sina keegi, sina mina, } \\
\text { teine kumb, teine see, tema üks, üks iga, üks see }\end{array}$ \\
\hline S-S & 21 & $\begin{array}{l}\text { algamine ilm, and jumal, arm jumal, kogudus jumal, rahu } \\
\text { jumal, sulane jumal, sõna jumal, tee jumal, tunnistaja } \\
\text { jumal, vaim jumal, viha jumal }\end{array}$ \\
\hline S-H & 20 & $\begin{array}{l}\text { ema Jeesus, imetegu Kristus, jumal Iisrael, koda Jaakob, } \\
\text { koda Taavet, mägi Siinai, pale Mooses, poeg Sebedeus, } \\
\text { päev Kristus, rahvas Iisrael, rist Kristus, sugu Iisrael, suu } \\
\text { Taavet, sõna Kristus, veri Kristus, vägi Kristus }\end{array}$ \\
\hline V-P & 15 & $\begin{array}{l}\text { kuulma tema, kuulma üks, nimetama see, olema keegi, } \\
\text { olema mina, olema see, panema tema, saama mõlema, } \\
\text { saama sina, saama tema, võima tema, ütlema mina, } \\
\text { ütlema mõningas }\end{array}$ \\
\hline
\end{tabular}




\begin{tabular}{|c|c|l|}
\hline $\begin{array}{c}\text { Sõnaliik- } \\
\text { sõnaliik* }\end{array}$ & $\begin{array}{c}\text { Sage- } \\
\text { dus }\end{array}$ & \multicolumn{1}{|c|}{ Tõlketi vahetuses olevate sõnade paarid } \\
\hline V-D & 13 & $\begin{array}{l}\text { laskma mitte, olema ei, olema mitte, pidama mitte, } \\
\text { saama ka, saama mitte, saama palju, tulema siis, uskuma } \\
\text { mitte, võima mitte }\end{array}$ \\
\hline P-D & 12 & mina ei, mina ka, see nüüd, sina ei, sina siis, tema ei \\
\hline P-V & 9 & $\begin{array}{l}\text { enese laskma, mina kirjutama, mina olema, see pidama, } \\
\text { see tulema, sina uskuma, tema nägema, tema olema, } \\
\text { tema paluma }\end{array}$ \\
\hline S-P & 9 & $\begin{array}{l}\text { amet mina, jalg mina, jalg sina, jumal mina, jünger tema, } \\
\text { lihavõte see, vaim see, variser üks }\end{array}$ \\
\hline D-D & 9 & $\begin{array}{l}\text { ikka veel, ka mitte, mitte enam, mitte ka, mitte veel, } \\
\text { nüüd ka, palju enam }\end{array}$ \\
\hline K-P & 8 & $\begin{array}{l}\text { pärast tema, sees kumb, vastu mina, vastu see, vastu } \\
\text { teine, üle tema, ümber sina }\end{array}$ \\
\hline D-V & 5 & $\begin{array}{l}\text { enam saama, hukka minema, mitte armastama, siit } \\
\text { tahtma, ära unustama }\end{array}$ \\
\hline P-H & 5 & kõik Seba, mina Mooses, see Jeesus, tema Heroodes \\
\hline P-S & 5 & see liha, see ülestõusmine, tema jumal, tema kivi \\
\hline A-V & 4 & hea tegema, raske saama, vaba saama, ühesarnane olema \\
\hline V-H & 4 & $\begin{array}{l}\text { astuma Jeesus, astuma Peetrus, kostma Peetrus, minema } \\
\text { Jeruusalemm }\end{array}$ \\
\hline V-J & 4 & \begin{tabular}{l} 
kostma ning, kuulma ning, olema ning, pidama ehk \\
\hline Sorationa
\end{tabular} \\
\hline
\end{tabular}

* Sõnaliigi tähised: A - adjektiiv, D - adverb, $\mathrm{H}$ - pärisnimi, J - konjunktsioon, $\mathrm{K}$ - pre-/postpositsioon, $\mathrm{P}$ - pronoomen, $\mathrm{S}$ - substantiiv, $\mathrm{V}$ - verb (vt http://www.filosoft.ee/html_morf_et/morfoutinfo.html).

Sagedasimate sõnapaaride kokkuvõtva tabeli 11 alusel saab öelda, et sõnaliigiti on kõige enam vahetatud järjekorraga paare kategooriates verbverb (V-V) ja pronoomen-pronoomen (P-P). Nende esinemissagedused on vastavalt 44 ja 45 . Kolmandana kõige enam ehk 21 korral esineb mustrit substantiiv-substantiiv (S-S). Lähemal vaatlusel selgub, et kõigil kolmanda rühma juhtudel on tegu paaridega, mis Stahli tõlkes moodustavad tänapäevase genitiivühendi, Rossihniuse tõlkes aga vana kirjakeele pärase nn ablatiivgenitiivi. Seejuures on 20 juhul paari üks substantiive sõna jumal (näide 10). Ainult ühel korral on kasutatud muid substantiive (näide 11). 
(10) Rm 10:17

R: siis tulema see usk see jutus see jutus ütlemine enge läbi see sõna jumal

R: Sihs tulleb se usck sest juttussest, sest juttusse ütlemine enge lebbi se sönna Jummalast.

S: siis tulema see usk see jutlus see ütlemine aga läbi see jumal sõna

S: Sihs tullep se usck sest ütlussest / se ütleminne agkas lebbi se Jummala Sanna.

(11) Mt 25:34

R: ... mina isa pärandama see rikkus mis sina valmistama olema algamine ilm

R: ... minnust Issast, perrandaket se rickusse, mea teile walmistut om alckmissest ilmast.

S: ... mina isa pärandama see rikkus kumb sina valmistama olema see ilm algamine

S: ... münnust Issast / perrandaket se rickusse / kumb teile walmistut on sest ilma algkmissest.

19 esinemisjuhuga on sageduselt neljas muster substantiiv-pärisnimi (S-H). Seda esindavad paarid, mis Stahli tõlkes esinevad tekstitasandil genitiivühendina, milles omajat väljendab pärisnimi. Rossihniuse tõlkes võivad need olla realiseerunud kahel viisil. Esiteks, paari tagumiseks liikmeks olev pärisnimi võib samuti olla väljendatud ablatiivgenitiiviga, nagu eelmise mustri korral (4 juhtu, vt näide 12), kuid enamasti on Rossihniuse tõlkes paari tagumiseks liikmeks olev pärisnimi siiski genitiivis (10 juhtu, vt näide 13). Teiseks, viiel juhul on Rossihniuse variandis pärisnimi nominatiivis (näide 14).

(12) $2 \mathrm{Kr} 3: 7$

R: ... võima mitte nägema see pale Mooses see selgus pärast tema pale kumb ...

R: ... woi mitte netta sedda pallet Mosessest, se selgedusse perrast temmast palckest ,kumb

S: ... võima vaatama Mooses pale peale see selgus pärast kumb tema pale

S: ... woinut wallatama Mose palle pehle / se selgkedusse perrast / kumb tem̃a palgkel ...

(13) Lk 1:33

R: ning tema saama üks kuningas olema üle see koda Jaakob igavelt ning tema kuningas ... 
R: ninck temma sahb ütz Kunnigas ollema ülle se koa Iacobi iggawelt, ninck temma Kunniga

S: ning tema saama üks kuningas olema üle see Jaakob koda igavesti ning tema ...

S: ninck tem̃a sahp üx Kunningas olla ülle se Jacoba kodda igkawest ninck temmast ...

(14) Lk 2:32

R: üks paistus paistma see pagan ning üks kiitus sina rahvas Iisrael

R: üttes paistusses paistma neile pagganeile, ninck üttes kittusses sinnu raghwalle Israel.

S: üks küünal paistma see pagan ning üks kiitus oma Iisrael rahvas

S: Öhex Kühnlax paistma neile pagkanalle / ninck öhex kihtussex ommal Israelli rahwal.

Väiksema sagedusega mustreid ei ole siinkohal võimalik lähemalt analüüsida. Esialgsel vaatlusel tundub, et kahe tõlketeksti sarnasuse või erinevuse seisukohalt on need juhuslikumat laadi.

Nagu eelnevast nägime, on vahetatud järjega sõnapaaride hulk (264) sama järjekorraga sõnapaaride hulgaga (13 789) võrreldes väike, moodustades vaid $\mathrm{ca} 1,9 \%$ koguhulgast. Vahetatud sõnapaaride väikest osakaalu ja mõju kajastab ka KSi ja NPÜAJ Pearsoni korrelatsioonikordaja väärtus 0,835 , mille alusel saab väita, et kahe tõlketeksti vahel valitseb ühiste sõnade järjekorda arvestades väga tugev positiivne lineaarne seos.

Tõlkesalmide analüüs osutab, et tekstisõnade tasandil on tõlkesalmide üldine omavaheline sarnasus küllaltki väike, kuid see suureneb märgatavalt, kui minna tekstisõnadelt üle algvormidele. Seda järeldust illustreerivad kõige paremini joonis 2 ja selle selgitused. Lisaks, vaid ca $2 \%$ juhtudest on tõlketi kõrvuti esinevate sõnade järjekorras erinevusi. Kõige enam puudutab see paare V-V ja P-P, seejärel paare S-S ja S-H.

Kokkuvõttes võib öelda, et kvantitatiivse analüüsi põhjal on kaks tõlget omavahel üsna sarnased. Sarnasust näitavad mõlema tõlke küllaltki ühesugune leksikaalse mitmekesisuse ja tiheduse protsent (valemid 1 ja 2), peaaegu eristamatud sisusõnade osakaalud (tabel 1), aga ka ühissõnade küllaltki ühesugune osakaal tõlgetes (joonis 1). Sarnaseid jooni leidub ka sagedasimate adjektiivi-substantiivi (A-S) paaride hulgas (tabel 8), ent ka tõlketekstide võrdlemisel algvormide tasandil. Ilmnes, et ca 70\% tõlkesalmidest on koosinussarnasusega $65-85 \%$ (vt joonis 2 ). 
Suuremad erinevused ilmnevad ortograafias, kus mõlema tõlke kõige mitmekesisemate näidete tabelites 2 ja 3 ei olnud ühtegi kokkulangevat algvormi. Suured erinevused torkavad silma ka naabersõnade võrdlusel. Nimelt, kui kollokatsioonide leidmiseks kasutada spetsiaalseid statistikuid, ilmneb, et tugevamate seostega naabersõnad on enamikul juhtudest tõlketi ainuomased (tabel 10).

\section{Kvalitatiivne analüüs}

Kvalitatiivne analüüs lähtub Rossihniuse ja Stahli perikoopide tõlkelisest vaatlusest ja kõrvutusest, aga ka laiematest tähelepanekutest, mis on korjunud eesti piiblitõlke ajaloolise konkordantsi koostamise käigus. Fraas-fraasilt on omavahel kõrvutatud ning Martin Lutheri piiblitõlke 1545. aasta (vajaduse korral ka 1534. aasta) versiooniga (Luther 1534, 1545) võrreldud kattuvaid perikoope vanast testamendist (Jesaja ja Malaki raamatust), uue testamendi Matteuse, Markuse ja Luuka evangeeliumist (viimasest 1., 2. ja 24. peatüki osa) ning Pauluse kirjadest roomlastele, korintlastele ja galaatlastele - kokku 729 salmi ehk 51,9\% kõigist ühistest salmidest. Analüüsi käigus on peale kahe tõlke omavahelise suhte täpsustamise püütud sihipäraselt leida ka võimalikke märke erinevatest ajalistest kihistustest ja tõlkestrateegiatest.

\subsection{Tõlkemeetodist}

Vanema kirjakeele tõlkelise aspekti kirjeldamisel näib mugav kasutada formaalse vastavuse ja dünaamilise ekvivalentsi mõisteid (Nida, Taber 1982). Ajastuomaseks ehk 17. sajandi esimesel poolel domineerinud tõlkemeetodiks võib pidada formaalset vastavust taotlevat tõlget, nagu see tuleb eriti ehedana esile Stahli perikoobiraamatu lõppu lisatud Jesaja raamatu peatüki eestinduses, mille lisamist põhjendab Stahl isiklikul toonil: „Kristlikule armsale lugejale, kuna natuke ruumi üle jäi, pidasin sobivaks (hat es mir gefallen) täita see vaimurikka prohvet Jesaja 53. peatükiga.“ Näib tõenäone, et vähemalt selle peatüki on Stahl ise tõlkinud. Tõlge on tehtud Martin Lutheri saksakeelsest tõlkest, kandes seda sõna-sõnalt, paiguti lausa morfeem-morfeemilt eesti keelde üle. Põhimõtteliselt sama tõlkemeetodit on rakendatud kõigis 17 . sajandi nelja esimese kümnendi säilinud tõlkekatkendites, ehkki mõningate vormelite või tekstiosade 
sõnastuses võib ilmneda lahknevusi saksa lähtesõnastusest. Tõenäoliselt annab see tunnistust vormeli või fraasi ammusest juurdumisest või kogu tekstiosa pärinemisest mingist teistsugusest, oletatavasti varasemast tõlketraditsioonist (vt lähemalt Ross 2000).

Tänapäevase ilukirjandusliku tõlkega võrreldes vastavad nii Rossihniuse kui ka Stahli perikoobid tervikuna üsna hästi formaalset vastavust taotlevale tõlkemeetodile. Suuresti just sellest võib olla tingitud ka nende omavaheline sarnasus: saksakeelse teksti sõnasõnalise ja morfeemmorfeemilise ülekande korral peavadki sihttekstid olema väga sarnased; varieeruda saavad ainult kasutatavad leksikaalsed vasted, nagu tuleb eriti selgesti esile juhtudel, kus Rossihniuse tekstis esineb lõunaeestiline, Stahli tekstis põhjaeestiline sõna (sehen $>$ kaema $\sim$ vaatama vms - vt asendussõnad alajaotises 3.2).

Lähemal vaatlusel näib kahe tõlke formaalse vastavuse määr olevat siiski veidi erinev. Nimelt tundub Rossihniuse tõlge taotlevat formaalset vastavust järjekindlamalt kui Stahli oma. Kummagi teksti tõlketehnilist eripära võiks illustreerida Mt 2:23 salmiosa (parema jälgitavuse huvides on näide esitatud osade kaupa).

a)

L: vnd kam vnd wonet

R: ninck tulli, ninck elli

S: ninck tulli / ninck ellas

c)

L: Auff das erfüllet würde

R: et sähl teutetut saj,

S: et töitetut sai / b) in der Stad, die da heisst Nazareth. se lihna sissen, kumb sähl sahb nimmetut Nazareth Nazaretti Linna sees

d)

das da gesagt ist durch die Propheten mea sähl ütteltut om lebbi se Propheti mea ütteltut on lebbi se Propheti

Esimene osa (a) on nii elementaarne, et siin olekski keeruline erinevalt tõlkida. Teises osas (b) kopeerib Rossihniuse versioon väga täpselt saksa lähteteksti, andes omaette vaste (sähl) isegi saksa partiklile $d a$, mida saksa keeles kasutati nominatiivse relatiivpronoomeni järel ilma selge tähenduseta (Grimm DA 4a). Ainsa kõrvalekaldena üksühesest vormilisest vastavusest edastatakse saksa sõnavormi heisst kahesõnalise passiivse fraasiga sahb nimmetut, mida võib pidada ajastuomaseks juurdunud tõlkevasteks. Seevastu Stahli versioonis on kogu fraas täiesti eestipäraseks lihtsustatud. Kolmandas osas (c) esineb Rossihniuse versioonis seesama sähl, ehkki saksa lähtefraasis see puudub, kuid lisandus võrdsustab lähte- ja sihtfraasi 
sõnade arvu. Neljandas fraasis (d) vastab Rossihniuse versiooni sähl taas saksa lähtefraasile.

Tõsi, leidub ka vastupidiseid näiteid, kus Stahli versioonis on mõni fraas tõlgitud täpsemini kui Rossihniusel, kuid üldjoontes tundub Rossihnius olevat formaalselt täpsem. Kuni selleni välja, et liittüveliste sõnade morfeemhaaval tõlkimise teel saadud eesti vasted võivad (vähemalt tänapäeva lugejale) olla Rossihniuse variandi eesti keeles üsna arusaamatud, samas kui Stahli variandis on neile antud dünaamiliselt ekvivalentne muutüveline vaste, $\mathrm{nt} 2 \mathrm{Kr}$ 6:6 R ilmaferwitut armu sissen $<\mathrm{L}$ in vngeferbeter liebe, vrd $\mathrm{S}$ tössisse armo sees; $2 \mathrm{Kr}$ 6:8 $\mathrm{R}$ need ümberwyat $<\mathrm{L}$ die verfürer, vrd S needt pettijat.

Mõnel juhul meenub Rossihniuse versiooni tõlkevasteid lugedes Uku Masingu hüpotees algtõlke autoriks olnud eestlasest, kes lihtsalt ei osanud saksa keelt ja tõlkis seetõttu mõne sõna täiesti valesti (Masing 1999: 266). Näiteks Gl 6:7 on saksa sich irren tõlgitud Rossihniuse versioonis vastega pahandama. Grimmide sõnaraamatu järgi võidi ilma enesekohase asesõnata verbi irren kasutada tõesti nii tähenduses 'turbare' ('segadusse ajama, häirima') kui ka 'errare' ('eksima'), kuid enesekohase asesõnaga verb on alati kandnud ennekõike tähendust 'eksima'. Siinkohal on 'eksima' ainuvõimalik tõlgendus ja just nii ongi fraasi mõistetud Stahli versioonis, vrd L Irret euch nicht $>$ R Errapahandakut hendas mitte, S Erra hexiket. Niisuguste ülekannete korral pole siiski selge, kas tõlkijana on loogilisem eeldada eestlast, kes ei saanud aru saksa keelest, või sakslast, kes ei saanud aru, mida tema sooritatud morfeemmorfeemiline ülekanne eesti keeles lõpuks tähendas.

Üldise üksühese vormilise vastavuse juures esineb Rossihniuse versioonis teatud tüüpi lisandusi. Nii on seal enamasti kohanimele lisatud sõna linn või maa, rahvanimele sõna rahvas, saksa nimisõna funktsioonis kasutatud adjektiivi vastele selgitav põhisõna jne, nt Mt 2:1 L zu Bethlehem, R Bethlehemmi linnan, S Bethlehemmis; Mt 2:2 L der Jüden, R sest Juda raghwast, S neist Judalissest; Mt 9:2 L einen Gichtbrüchigen, R ütte luhtöbbitze Inimesse, S öhe luhtöbbise. Stahli versioonis esineb selgitavaid lisandusi vähem ja ebasüsteemsemalt, aga see-eest on selles näiteid, kus ühele sõnale on antud mitu sünonüümset vastet, mille abil püütakse lähtesõna tähendust täpsustada, nt Mt 4:21 L jre netze flickten, R omma nohta parrandasit, S omma Nota paicksit / ninck kohendasit; Mt 9:12 $\mathrm{L}$ dürffen ... nicht, $\mathrm{R}$ ei olle mitte waya, $\mathrm{S}$ ep olle ... waja / ninck tarbis; 
Mt 11:21 (jm) L Wehe dir, R Haicke sinnule, S Hedda ninck waiw sünnul; $\mathrm{Rm}$ 8:23 L wir ... sehnen vns, $\mathrm{R}$ meye ... himmotzeme hendas, $\mathrm{S}$ meije ... igkatzeme ninck hingame issi hennesse sees; $1 \mathrm{Kr}$ 4:3 L ein geringes, $\mathrm{R}$ ütz weiti, S üx wehti ninck tühhine assi; 1Kr 13:4 L langmütig und freundlich, R pitkmehlelick ninck söbbralick, S tassane / kannatalick / ninck helde; $2 \mathrm{Kr}$ 6:1 L vergeblich, R ilmaaszjata, S ilmaasjatta ninck tühjast; G1 3:24 L Zuchtmeister, R johtaja, S oppija ninck ... johataja; G1 5:20 L Hadder, Neid, Zorn, Zanck, Zwitracht, Rotten, Hass, Mord, R rihd ninck wiha, kawal opmine, röwmime, S ridel / kaddedus / weeha / soimatus / kahet meelet / falsch oppetus / weehaminne / tapminne (ehkki viimase näite pikas loendis on keeruline täpseid vastavusi tuvastada).

Rossihniusel näib sünonüümseid vasteid esinevat vähem, samas on mõned neist küllaltki huvitavad. Näiteks Mt 22:37 esineb alliteratiivne paarisväljend seal, kus saksa originaalis on ainult üks sõna: $\mathrm{L}$ von ganzem Gemüt, R kihkest mehlest ninck möttest, vrd S keickest meelest. Paaris kohas on sünonüümsed vasted Rossihniusel esitatud seotuna mitte ühendava sidesõnaga, vaid vastandava sidesõnaga $e h k$, misjuures tõlkija näib pakkuvat saksapärasele võõrsõnale võimalikku eesti vastet, nt 1Kr 13:12 L durch einen Spiegel; R lebbi ütte Spegli ächk warjokajetawa, vrd S lebbi öhe Spegli; Lk 11:21 L sein Pallast bewaret; R omma pallasti ächk lihna hästi hojab, vrd S omma kodda hehste hoidap.

Üldiselt liigituvad mõlemad versioonid niisiis vormilist vastavust taotleva tõlke alla, kuid Rossihniuse versioonis on lähtetekstiga üksühese vastavuse taotlus silmatorkavam kui Stahli versioonis.

\subsection{Grammatilised konstruktsioonid}

Vormilist vastavust taotleva tõlke korral osutuvad problemaatiliseks grammatilised konstruktsioonid, mille ehitus peaks lähte- ja sihtkeeles põhimõtteliselt erinema. Saksa keelest eesti keelde tõlkimisel on suurimaid raskusi valmistanud objekti ja eituse vormistamine, valik kahe eesti keele infinitiivi vahel ning nimisõnalised sõnaühendid, mille vormistamisel eesti keeles peaks täiendsõna tänapäeva keeleloogika järgi olema genitiivis (mida siin edaspidi nimetatakse tinglikult genitiivühendeiks). Objekti vormistamisel ja õige infinitiivi valikul komistasid kõik varasema kirjakeele tõlkijad, kuid sellest aspektist kaht kriitilist perikoobiversiooni 
siinkohal ei võrrelda. ${ }^{11}$ Eituse ja genitiivühendite vormistamisel tuleb aga kahe versiooni vahel esile selge erinevus.

Eituse vormistamise probleemidest vanas kirjakeeles on palju kirjutatud (vt nt Kilgi 2012: 123-144), mistõttu pole tarvis probleemi olemust siinkohal selgitada. Mainitagu vaid, et Rossihniuse versioonis on eitus üldiselt rahvakeelepärane, Stahlil aga enamasti ekslik, s.t koosneb saksa keele eeskujul jaatusvormist ja muutumatu(te)st eituspartikli(te)st, nt Mt 4:4 L lebet nicht, $\mathrm{R}$ ej ella mitte, $\mathrm{S}$ ep ellap mitte. Seal, kus saksa keeles väljendab eitust üldeitav partikkel, osutub seesugune lähteteksti kopeeriv vormistus eesti keeles tegelikult jaatuseks, nt Mt 2:6 L du ... bist mitnichten, R sinna ... ei olle minckit sarnatzel kombel, S sinna ... ollet minckit sarnasel kombel. Eituse ekslik vormistus annab Stahli versioonile läbivalt võõrapärase ja kohmaka ilme.

Genitiivühendid on saksa keeles enamasti vormistatud nii, et täiendsõna jääb sõnaühendi lõppu. Eesti keeles peaks täiendsõna olema põhisõna ees. Selline ümberpööramine oli paljudele kirjakeele algusfaasi autoritele ilmselt liiga keeruline ning seetõttu arenes vanas eesti kirjakeeles välja saksa lähtemalli kopeeriv fraasimoodustus, milles kasutatud st-lõpulist täiendsõnavormi võiks nimetada ablatiivgenitiiviks. Ablatiivgenitiivi tundub Rossihniusel esinevat palju rohkem kui Stahli versioonis, kus nimisõnaühendeis on sageli kasutatud täiesti rahvapärast genitiivi ${ }^{12}$, vrd nt Mt 2:13 L der Engel des HERRN, R se Engel sest Issandast, S se Issanda Engel, Mt 21:5 L auff einem Füllen der lastbaren Eselin, R ütte warsa pähl sest kohrmakandja mötzhobbust, S öhe kohrmakandija metzhobbo warsa pehl. Stahli versioonis leidub rahvapärases genitiivkonstruktsioonis koguni ilusaid mitmuse vorme. Tõsi, mitmuse genitiivivorme kohtab Rossihniusegi tekstis, kuid ka nende korral võib täiend- ja põhisõna järjekord olla saksapärane, nt Lk 1:70 L Durch den Mund seiner heiligen

${ }^{11}$ Põhjaliku ülevaate infinitiivide kasutusest 17. sajandi põhjaeesti kirjakeeles annab Pille Penjami väitekiri (2008: 201-284).

12 Täpsemad arvulised andmed on esitatud kvantitatiivse analüüsi peatükis, kus käsitletakse vahetatud järjekorraga sõnapaare (vt 2.4.2). Kuivõrd seal analüüsitakse ainult bigramme, jäävad sealsest statistikast välja substantiivifraasid, mille korral on ühes või teises tõlkes kahe substantiivi vahel artikli funktsioonis sõna üks või see, nagu ablatiivgenitiivi korral enamasti tegelikult ongi. Seetõttu saab ablatiivgenitiivi tegelikust osakaalust kummaski tõlkes siinkohal rääkida siiski ainult lugemisel tekkiva mulje põhjal. 
Propheten, R lebbi se suh temma pöha Prophetide, vrd S lebbi ommade pöhade Prophetide suh. Muidugi esineb ka Stahli versioonis ablatiivgenitiivi, nt Mt 4:9 L alle Reich der Welt on mõlemas eesti versioonis ablatiivgenitiiviga ( $\mathrm{R}$ kihck rickusset sest ilmast, $\mathrm{S}$ keicke rickusse sest Ilmast), aga hinnanguliselt esineb Stahlil ablatiivgenitiivi siiski märksa vähem.

Niisiis võib kahe grammatilise konstruktsiooni, eituse ja genitiivfraasi analüüsi põhjal öelda, et eituse korral kopeeritakse Stahli versioonis enamasti saksa konstruktsiooni, samal ajal kui Rossihniusel esineb üldiselt eestipärane eitus. Genitiivkonstruktsiooni korral on aga olukord vastupidine: Stahlil esineb üsna palju rahvapärast genitiivi, Rossihniuse versioonis aga kasutatakse valdavalt ablatiivgenitiivi.

\subsection{Terminid ja vormelid}

Kuivõrd perikoobid on kristliku vaimuliku keele erialatekstid ja kristlikku sõnumit oli perikoopide ilmumise ajaks eesti keeles levitatud juba neli sajandit, siis on selge, et kesksete mõistete ja sagedaste vormelite väljendamiseks oli kujunenud traditsioon ning teatud vasteid kasutati 17. sajandi alguses sõltumatult ajastu tõlkemeetodist. Juurdunud terminiteks ja vormeliteks võib pidada kõiki perikoopides regulaarselt kasutatud kristliku tuumikleksika vasteid, eriti kui need ei ole morfeem-morfeemilt tuletatud Lutheri saksakeelsest lähteterminist või -vormelist. Osa niisuguseid termineid ja vormeleid olid põhja- ja lõunaeesti kirjakeelele ühised, osa erinevad. Osa on ilmselt pärit juba reformatsioonieelsest ajast, osa 16. sajandist. Ühised tõenäoliselt juurdunud terminid ja vormelid on nt ristima (sks taufen), rist (sks Kreuz), kirjatundja (sks Schriftgelehrte), patt (sks Sünde), andeks andma (sks vergeben), lausuma ( ̈̈tlema, pajatama kellegi) vastu (sks sprechen $\sim$ sagen zu), kuri (hea vastandina). Siiski äratab tähelepanu, et 17. sajandi alguses ilmunud tekstides võib veel nendegi terminitega seoses probleeme ilmneda. Näiteks eesti rist-tüve kahetähenduslikkus on põhjustanud arusaamatusi mõlemas perikoobiversioonis. Ehkki saksa verbi kreuzen on üldiselt tõlgitud sõnaühendiga risti peale panema $\sim$ pooma, leidub siiski ka üks mõlemas versioonis kattuvalt eksitav koht: Mk 16:6 L den gecreutzigten, R sedda ristitut, $\mathrm{S}$ ke ristitut on; Rossihniuse versioonis on lisaks paaris kohas antud saksa originaali sõnale Taufe vasteks rist, nt Mt 20:23 L mit der Tauff, R se risti kahn (vrd S se ristmisse kahs). Väärib esiletoomist, et kristlikuks terminiks 
kujunenud sõna kuri kasutatakse esimestes säilinud perikoopides veel väga laias tähenduses 'kõlbmatu, halb', nagu kinnitab ilmekalt näiteks väljend kuri puu Mt 7:17 (ja 18) mõlemas variandis: L ein fauler Bawm, R ütz kurri puh, S üx kurri puh.

Eriti üllatav on ühine vormel, mis esineb mõlema perikoobiversiooni Luuka evangeeliumi ingli tervituses: Lk 1:28 L Gegrüsset seistu holdselige, R Terwetut olle sinna armuteus, S Olle terwe / sinna armo töis. Eesti vaste armu täis ei saa kuidagi tuleneda Lutheril kasutatud väljendist Holdselige, vaid peab olema toortõlge vastavast ladina fraasist gratia plena. Just seda fraasi kasutas Luther näitena oma tõlkemeetodi kirjeldamisel, selgitades, kui sobimatu on siinkohal ladina fraasi sõna-sõnalt üle kanda (Luther [1530] 2000: 89-90). Muidugi ei saa eeldada, et eesti perikoobitõlkijad oleksid olnud Lutheri tõlkealase kirjaga tuttavad, kuid seesugune kasutus tõestab, et väljend pidi juurduma juba katoliku ajal, mil see tõlgiti kas ladina keelest või mõnest Vulgata-pärasest saksa tõlkest sõna-sõnalt eesti keelde. Väljendi varane juurdumine on eriti ootuspärane, kui arvestada, et vaadeldavat kirjakohta sisaldav palve oli katoliku ajal üks olulisimaid. ${ }^{13}$

Perikoobitekstide ulatuses oli ilmselt kujunenud ka mingi lõdvem traditsioon, mida järgiti selliste väljendite edasiandmiseks, mida ei saa pidada otseselt vaimuliku keele osaks, vaid mis kuuluvad pigem üldkeelde. Nii võib mõlemas versioonis kohata mõningate saksa keelendite korral ühesuguseid või lähedasi vasteid, mida ei saa saksa keelendist morfeemmorfeemilt tuletada, ilma et see pruugiks ilmtingimata öelda midagi versioonide võimaliku ühise päritolu kohta, nt Lk 1:75 L Die jm gefellig ist, $\mathrm{R}$ kumb temma mehle perrast om, $\mathrm{S}$ kumb temma meele perrast on.

Osa varaselt juurdunuks peetavast vastevarast võib pisut varieeruda või olla lõuna- ja põhjaeesti traditsioonis selgelt erinev (vt asendussõnade kohta kvantitatiivse analüüsi ptk 3.2). Näiteks saksa terminile Heiland, mis esineb kattuvates perikoobiosades kokku kuus korda, on Stahli versioonis alati vasteks õnnistegija, Rossihniuse versioonis enamasti lunastaja, nt Lk 2:11 L der Heiland, R se lunnastaja, S se önnistegkija (üks kord, Tt 3:6, esineb siiski ka Rossihniuse versioonis önnisteggia). Erinevad on ka saksa terminile Gesetz antud vasted: selle edasiandmisel kasutatakse

${ }^{13}$ Kuivõrd Stahli perikoobid ilmusid ka käsiraamatu 2. ja 3. trükis peaaegu muutmata kujul, esineb kõnealune Vulgata-pärane väljend (nii nagu ka segadused rist-tüve kasutamisel) veel 1693. aasta käsiraamatuski. 
Stahli versioonis enamasti sõna käsk, Rossihniuse versioonis sõna seadus, nt Lk 24:44 L im gesetz Mosi, R Mosesse Sädusse sissen, S Mosesse kescko sees. Seal, kus saksa tekstis esineb samas fraasis ka sõna Gebot, võib Stahli versiooniski olla sõna Gesetz vasteks seadus, nt Mt 22:36 L das furnemest Gebot im Gesetz, R se kihke suhremb kesck se sädusse sissen, $\mathrm{S}$ se üllemb kesck sehdusse sees.

\section{4. Üldkeelsed fraseologismid}

Termini- ja vormelilaadsetest keelenditest eraldi tasub käsitleda tavalisi üldkeelseid fraseologisme, mille edasiandmisel näib Stahli versioon üldiselt ilmutavat suuremat dünaamilisust kui Rossihniuse oma. Sagedased on juhud, kus Rossihniuse versioonis on keelend üle kantud sõna-sõnalt, ent Stahli versioonis on fraasile antud sisuliselt ekvivalentne dünaamiline vaste ning vajaduse korral on lisatud sõnu, mida originaalis otseselt pole, või sõnastatud fraas täiesti ümber, nt Mt 9:1 L fuhr wider herüber, R letz jelle ülle, S lasckis hend souda ülle se merre; Mt 20:6 L den gantzen Tag, R kihke se peiwa, S keicke piddusse pehwa; Mt 22:16 L denn du achtest nicht das ansehen der Menschen, R sest sinna ei kaje mitte neine Inimeste suhrusse pähle, S sest sinna ep piddat öhest innimessest ennamb lugku / kudt sest töisest; Lk 1:36 L im geschrey ist das sie vnfruchtbar sey, R kumb pajatusse sissen om, et temma ilmasuggulick om, S kennest üttelti / eth ep temma eales piddi lapse ilmale kandma; Lk 2:36 L nach jrer Jungfrawschafft, R perra omma Iunckroliko saisust, S abbi ello siddes; $2 \mathrm{Kr}$ 4:7 $\mathrm{L}$ in jrdischen Gefessen, $\mathrm{R}$ neine ilmliko annummette sissen, $\mathrm{S}$ muldasede ihode sees. Vahel ilmutab ka Rossihniuse variant keerulisemate väljendite edasiandmisel teatud dünaamilisust, kuid nendeski kohtades on Stahli versioonis oldud tavaliselt veel leidlikum, nt Rm 8:38 L weder gegenwertiges noch zukünfftiges, R ächk mea silmade ehn om, ächk mea tullewelick om, $\mathrm{S}$ ep mea sündip / echk weel sündima sahp.

Fraseologismide dünaamiline tõlkimine piirneb juhtudega, mida võib peaaegu pidada erinevaks tõlgenduseks. Näiteks salmis Js 40:2 esineb Lutheril fraas Das jre Ritterschafft ein ende, mille kohta Luther peab vajalikuks ääremärkuses selgitada, et Ritterschaft tähendab siin jumalateenistust vanas testamendis. Rossihniuse tõlge on üsna pisut selgitav: et neine waimoliko söddal ütz tucka om; Stahli tõlge aga läheb kaugemale ja seletab pigem Lutheri servamärkust kui teksti ennast: et se rasck 
kohrm sest kesckust nende pehlt on errawottetut. Piiblikohas Mt 6:30, kus inimest võrreldakse täna kasvava ja homme häviva rohuga, on Lutheri tõlkes viimase kohta öeldud das ... morgen in den ofen geworffen wird, mille Rossihniuse versioon täpselt nii ka edasi annab: kumb ... hohmen se ahju sisse heitetud sahb. Stahli versioonis aga kasutatakse siinkohal hoopis muud kujundit: kumb ... home maha nitetaxe, mis haakub (ehkki ei kattu) pigem teiste piiblikohtadega, kus rohtu või lille tarvitatakse inimese kaduvuse võrdkujuna (vrd Ps 103:15, Ii 14:2 jm).

\subsection{Keeleliselt kattuvad fragmendid}

Kuigi kaks perikoopide versiooni on lähivaates kogumuljelt üsna erinevad, leidub neis siiski hulgaliselt leksikaalse valiku ja grammatilise vormistuse poolest täiesti kattuvaid fraase, mis erinevad ainult ortograafia või murdelise vormitunnuse poolest, ning veelgi enam fraase, mis erinevad küll sõnavaliku poolest, ent mille korral sõnavalik on tingitud murdeerinevustest (vt taas asendussõnade kohta kvantitatiivse analüüsi ptk 3.2). Osa niisugustest fraasidest võib liigitada sedavõrd elementaarsete kilda, et neid olekski raske kuidagi teisiti tõlkida. ${ }^{14}$ Terminite ja vormelilaadsete väljendite korral saab kattuvust selgitada pikaajalise traditsiooniga, nagu öeldud. Sellest hoolimata esineb selliseidki kokkulangevusi, mida on raske selgitada tõlkemeetodi või traditsiooniga ning mis näivad igal juhul viitavat mingile ühisele lähtetõlkele. Nagu Külli Habicht on katekismuste kõrvutuses esile toonud, kehtib ka perikoopide korral üldtendents: mida keerulisem tekst, seda suuremad erinevused..$^{15}$ Seetõttu on ootuspärane, et üldmuljelt on evangeeliumide tõlked sarnasemad kui epistlite tõlked. Seda silmatorkavamad on mõningad epistlites esinevad sõnavalikulised kokkulangevused, nt 1Kr 9:24 L so in den Schrancken lauffen, R kumbat sähl kichla weddanut ommat, S kumbat johxmisse pehle kihla weddawat. Esineb ka ühiseid lahknevusi Lutheri tekstist, mille korral kummaski

${ }^{14}$ Tõlkevõrdluses, millega püüti hinnata eesti, läti, soome ja rootsi varaste tõlgete n-ö Lutheri-pärasust, selgus, et isegi kõige Lutheri-kaugemas versioonis, mis oli ilmselgelt tõlgitud heebrea originaalist, mitte Lutheri saksakeelsest tõlkest, langes 49\% fraasidest struktuuri poolest kokku Lutheri tõlkega (vt Ross 1995).

${ }^{15}$ Kvantitatiivse analüüsi käigus välja selgitatud kõige erinevamate piiblisalmide (vt 3.4) lähivaatlusel nähtub, et algvormide tasandil 43 kõige erinevamast salmist esindavad 31 epistlite teksti ja 12 evangeeliumide teksti. 
eesti versioonis on küll erinev vaste, kuid üks eesti vaste on tuletatav pigem teisest eesti vastest, mitte Lutheri tekstist, nt 2Kr 3:6 L Nicht des Buchstabens, ... Denn der Buchstaben tödtet, R ei mitte sest sädussest, ... Sest se sädus tappab, S mitte sest kesckust / ... Sest se kesk surretap; G1 4:27 L die Einsame hat, R selle jellejettetul om, S sel / ke ilma meeheta on / ommat.

Mõne kokkulangevuse korral on raske otsustada, kas tegu on lihtsalt vormilist vastavust taotlevate tõlgetega, juurdunud vormeliga või tuleks kattuvuse põhjust otsida ühisest lähtetõlkest, vrd nt Mt 8:12 (ja 22:13) L heulen und zeenklappen, $\mathrm{R}$ hulckmine ninck hambakerrisemine, S hulluminne ninck hambakerriseminne; $1 \mathrm{Kr}$ 13:1 L ein donend Ertz oder eine klingende Schelle, R ütz kummiseja wasck ächk helliseya kuhljus, S üx kummiseja wasck / echk helliseja kuhljux. Viimase väljendi toob, muuseas, üksikvastete ja fraaside kokkulangevuse esimese näitena esile juba Reiman (1898: XXXV-XXXVI), lisades vastava loendi lõpus: „See ei saa olla pimeda juhuse ajel toimunud. Me ei leia siin muud selgitust, kui peame eeldama ühist allikat, millest nii Stahl kui ka Rossihnius on ammutanud." Ometi tõusevad selle Esto mihi-pühapäeva ehk viimase paastueelse pühapäeva epistli (1 Kr 13:1-13) eri versioonides esile ka mõned iseäranis erinevalt sõnastatud salmid (vrd näited 15 ja 16).

(15) $1 \mathrm{Kr} 13: 4$

R: Se arm om pitkmehlelick ninck söbbralick, se arm ei olle mitte kadde, se arm ei olle mitte wallato, temma ei puhu hendas mitte ülles,

S: Se arm on tassane / kannatalick / ninck helde / se arm ep weehap mitte / ninck ep olle kadde / se arm ep teep kurja / temma ep körgkistap

(16) $1 \mathrm{Kr} 13: 8-9$

R: Sell armul ei olle eales mitte ütz tucka, kun toch sell tähendamissel neist tullewast asjast ütz tucka sahma sahb, ninck neil kehlil ütz tucka sahma sahb, ninck sel tundmissel ütz tucka sahb. Sest meije tehdmine om ilmateutelick, ninck meye tähendamine om ilmateutelick,

S: Se arm ep löppep / kus doch keick kuhlutamisset sahwat löpma / ninck keick keelet sahwat löpma / ninck se tundminne kahs sahp löpma. Sest meije tundminne ep olle töitelick / ninck meije kuhlotaminne ep olle töitelic.

Viimased kaks salmi kuuluvad kvantitatiivse analüüsi põhjal koguni 40 kõige erinevamalt tõlgitud salmi hulka. Seega tundub tervikperikoobi 
versioone kõrvutades, et tõlkevaste kumseja vask ehk heliseja kuljus kuulub pigem suulises traditsioonis varakult kinnistunud vormelite hulka, mitte ei pärine kahe tõlke ühisest kirjalikust allikast.

Kui epistlite sõnavalikus torkavad silma ennekõike üksikud üllatavad kokkulangevused, ent tervikuna kokkulangevaid pikemaid lauseid või lauseosi peaaegu ei esine, siis lihtsama keelega evangeeliumides leidub ka väga suurel määral kokkulangevaid pikemaid lõike, mille sarnasust näib tõesti olevat kõige kergem seletada ühist lähtetõlget eeldades. Näiteks Matteuse evangeeliumi 11. peatüki perikoopides esindatud algusosa Mt 11:2-10 on kahes väljaandes pea kattuva sõnastusega (kui murdeerinevused kõrvale jätta ja ignoreerida mõningaid Rossihniuse versioonile omaseid saksapärasusi), samas edasine osa, Mt 11:20-30, on küllaltki erinev. Tundub kõnekas, et kattuv lõik on kolmanda advendi evangeelium, lahknev lõik kuulub aga pühakupäevade evangeeliumide hulka, kusjuures Stahlil jaguneb see kahe pühakupäeva (Tallinna tänupäeva ja apostel Mattiase päeva) vahel eri lõikudeks, Rossihniusel kuulub aga tervikuna apostel Mattiase päeva juurde. Selle järgi võiks spekuleerida, et olulisimate pühade evangeeliumid juurdusid varem ja kindlama traditsioonina. Üldkehtiv reegel see siiski kindlasti pole, sest näiteks jõuluevangeelium Lk 2: 1-14; 15-20 on kummaski tõlkes selgesti erinev (Stahlil pealegi jälle kaheks jaotatud, Rossihniusel ühes tükis).

Perikoopide liigenduses ja valikus esineb kahe versiooni vahel muidki väiksemaid erinevusi kui eelmises lõigus mainitud juhud. Sedalaadi lahknevuste täpsem analüüsimine eeldaks liturgia ajaloo alast kompetentsi ning oleks kahtlemata vajalik kummagi perikoobiraamatu sünniloo rekonstrueerimisel. Kirjakeele arengu ja tõlkeloo vaatluses kinnitab seesuguste erinevuste olemasolu igatahes veel kord juba eelnevast tõlkeanalüüsist koorunud veendumust, et vaatamata üksikute perikoopide peaaegu täielikule kokkulangevusele, mida on võimalik seletada vaid ühise lähtetõlke olemasolu kaudu, ei saa Rossihniuse ja Stahli perikoobiraamatuid tervikuna kindlasti käsitleda teineteise või ühise eelkäija koopiana.

\section{Kokkuvõte}

Kvantitatiivse ja kvalitatiivse analüüsi kokkuvõtteks võib niisiis kinnitada varasemate uurijate tõdemust, et Rossihniuse ja Stahli perikoobid on väga mitmekihiline materjal, mis annab pildi 17. sajandi alguse tõlkemeetodist, 
kuid sisaldab kindlasti ka suulises traditsioonis kinnistunud väljendeid ning fragmente varasematest kirjalikest tõlgetest.

Kvantitatiivne analüüs tõi esile kahe tõlke suure sarnasuse, mis on tõenäoselt tingitud eeskätt formaalset vastavust taotlevast ajastuomasest tõlkemeetodist. Erinevused ilmnesid peamiselt ortograafias, mis oli 17. sajandi alguses veel välja kujunemata. Huvitavaid lahknevusi pakkus siiski ka naabersõnade kõrvutus, mis annab kinnitust näiteks oletusele, et nn genitiivkonstruktsioonide vormistamisel on kummaski tõlkeversioonis käitutud erinevalt. Esialgne kvantitatiivne analüüs ei võimalda paraku otsustada, kas tuvastatud lahknevused viitavad kummagi tõlke erinevale päritolule või on tingitud hilisemast toimetamisest. Erinevuste edasisel uurimisel tuleks võtta lähema vaatluse alla harva esinevad keelendid ning kõige nõrgemalt seotud salmid, samuti tasuks analüüsida perikoobitõlgetes esile tulevate erandlike vastete seoseid kummagi autori muu säilinud keelematerjaliga.

Kvalitatiivne analüüs lubab väita, et mõlemas versioonis leidub näiteid, mis annavad tunnistust tõenäoselt juba katoliku aega ulatuvast väljendustavast. Termini- ja vormelikasutuse kokkulangevust kahes tõlkes võibki seletada juurdunud traditsiooniga. 17. sajandi algupoole tõlketraditsiooni raames on siiski tegu kahe selgesti eriilmelise tõlkega: Rossihniuse versioon vastab vormiliselt täpsemini saksa tõlkele, Stahli oma on dünaamilisem ja sisaldab rohkem Lutherist lahknevat rahvakeelset väljendust. Mõlemad versioonid sisaldavad ilmselt varasemast ajast pärinevaid fragmente ja nende üha ületoimetatud kihte. Osa perikoopide korral näib tõenäone oletada ühise kirjaliku alustõlke olemasolu. Enamik tekstist ei anna ühise allika hüpoteesile siiski mingit kinnitust ning tõlgete läheduse põhjuseks võib pigem pidada tõlkemeetodit ja juurdunud vaimuliku keele traditsiooni. Osa perikoope on täiesti ilmselgelt iseseisvad tõlked.

Praegune teksti märgendus võimaldas kvantitatiivselt kõrvutada ainult salme või tervikpeatükke. Võimalikule ühisele kirjalikule allikale tuginevate perikoopide väljasõelumiseks tasuks edaspidi kvantitatiivselt kõrvutada kahte versiooni perikoopide kaupa, neutraliseerides ühtlasi kummalegi tõlkele eriomaste sünonüümide kasutamisest tingitud erinevused ning muud n-ö toimetaja parandustena tõlgendatavad lahknevused. 


\section{Kirjandus}

Annus jt 2000 = Endel Annus, Tiina Aasmann, Ülvi Kalpus, Pärja Miljan. Eestikeelne raamat $1525-1850=$ Estnisches Buch $1525-1850=$ Estonian book 1525-1850. Tallinn: Eesti Akadeemiline Raamatukogu.

Evert, Stefan 2009. Corpora and collocations. - Corpus Linguistics: An International Handbook, Vol 2. Ed. Anke Lüdeling, Merja Kytö. Berlin, New York: Mouton de Gruyter, 1212-1248.

Gomaa, Wael H., Aly A. Fahmy 2013. A survey of text similarity approaches. International Journal of Computer Applications 68 (13), 13-18.

Gries, Stefan Th. 2013. 50-something years of work on collocations. - International Journal of Corpus Linguistics 18 (1), 137-165. https://doi. org/10.1075/ijcl.18.1.09gri.

Grimm $=$ Deutsches Wörterbuch von Jacob Grimm und Wilhelm Grimm auf CD-ROM und im Internet. www.dwb.uni-trier.de/de/.

Gutslaff, Johannes 1998 [1648]. Observationes grammaticae circa linguam esthonicam. Grammatilisi vaatlusi eesti keelest. Tõlk. ja koost. Marju Lepajõe. (= Tartu Ülikooli eesti keele õppetooli toimetised 10.) Tartu: Tartu Ülikooli Kirjastus.

Habicht, Külli 2003. Kahe 1632. aasta katekismuse keelelistest kokkupuutepunktidest. - Vana kirjakeel ühendab. Artiklikogumik. Toim. Valve-Liivi Kingisepp. (= Tartu Ülikooli eesti keele õppetooli toimetised 24.) Tartu: Tartu Ülikooli Kirjastus, 9-27.

Huang, Anna 2008. Similarity measures for text document clustering. - Proceedings of the Sixth New Zealand Computer Science Research Student Conference (NZCSRSC2008). Christchurch, 49-56.

Inkpen, Diana Zaiu, Graeme Hirst 2003. Automatic sense disambiguation of the near-synonyms in a dictionary entry. - Computational Linguistics and Intelligent Text Processing. Ed. Alexander Gelbukh. Berlin, Heidelberg: Springer, 258-267. http://dx.doi.org/10.1007/3-540-36456-0_25.

Johansson, Victoria 2009. Lexical diversity and lexical density in speech and writing: a developmental perspective. - Lund University Department of Linguistics. Working Papers 53, 61-79.

Kilgi, Annika 2012. Tõlkekeele dünaamika Piibli esmaeestinduse käigus: verbi morfosüntaksi areng ja lõplik toimetamisfaas. (= Tallinna Ülikooli humanitaarteaduste dissertatsioonid 27.) Tallinn: Tallinna Ülikool.

Kingisepp jt 2002 = Valve-Liivi Kingisepp, Külli Habicht, Külli Prillop. Joachim Rossihniuse kirikumanuaalide leksika. (= Tartu Ülikooli eesti keele õppetooli toimetised 22.) Tartu: Tartu Ülikooli Kirjastus.

Luther, Martin 2000 [1530]. Kiri tõlkimisest ja pühakute eestpalvest. - Vikerkaar 2-3, 83-96. 
Luther, Martin 1534 = Biblia das ist / die gantze Heilige Schrifft Deudsch. Wittemberg: Hans Lufft. (Faksiimile: Taschen, 2003.)

Luther, Martin 1545 = Biblia. Das ist: Die gantze Heilige Schrifft / Deutsch / Auffs new zugericht. Wittenberg: Hans Lufft. (Faksiimile: Deutsche Bibelgesellschaft.)

Manning, Christopher, Hinrich Schütze 1999. Foundations of Statistical Natural Language processing. Cambridge, London: The MIT Press.

Masing, Uku 1964. Hans Susi 1551. a. tõlkest. - Emakeele Seltsi aastaraamat 10 (1964). Tallinn: Eesti NSV Teaduste Akadeemia, Emakeele Selts, 121-136.

Masing, Uku 1999. Eesti vanema kirjakeele lood. Tartu: Ilmamaa.

Miller, George A. 1998. Nouns in WordNet. - WordNet: An Electronic Lexical Database. Cambridge: The MIT Press, 24-45.

Nida, Eugene A., C. R. Taber 1982. The Theory and Practice of Translation. Leiden: Brill.

Pazienza jt 2008 = Maria Teresa Pazienza, Armando Stellato, Alexandra Tudorache. A Bottom-up Comparative Study of EuroWordNet and WordNet 3.0 Lexical and Semantic Relations. - LREC 2008.

Penjam, Pille 2008. Eesti kirjakeele $d a$ - ja $m a$-infinitiiviga konstruktsioonid. (= Dissertationes philologiae estonicae Universitatis Tartuensis 23.) Tartu: Tartu Ülikooli Kirjastus.

Reiman, Wilhelm 1898. Einleitung. - Südestnische Uebersetzung des Lutherischen Katechismus, der Sonntags-Evangelien und-Episteln und der Leidensgeschichte Jesu [...] (Verhandlungen der gelehrten Estnischen Gesellschaft, 19.) Tartu: H. Laakmann, III-LIV.

Rosenplänter, Johann Heinrich 1816. Über zwei Bücher von Rossihnius. Beiträge zur genauern Kenntniß der ehstnischen Sprache. 5. Heft, S. 13-36.

Ross, Kristiina 1995. Ülemlaulu tõlkest esimeses eestikeelses Piiblis. - Akadeemia 1, 3-29.

Ross, Kristiina 2000. Tõlketehnilisi küsimusi eesti kirjakeele algusaegadest: 2. käsk. - Keel ja Kirjandus 11, 781-795.

Rossihnius, Joachim 1898 [1632]. Evangelia und Episteln auf alle Sonntage durchs gantze Jahr. - Südestnische Uebersetzung des Lutherischen Katechismus, der Sonntags-Evangelien und -Episteln und der Leidensgeschichte Jesu [...] (Verhandlungen der gelehrten Estnischen Gesellschaft, 19) Tartu: H. Laakmann, 67-180.

Stahl, Heinrich 1638. Hand- und Hauszbuches Für die Pfarherren und HauszVäter Estnischen Fürstenthumbs, Dritter Theil, Darinnen die gewöhnliche Evangelia und Episteln durchs gantze Jahr [...] Tallinn: Chr. Reusners Sel. Nachgelassener Widwen Drückerey. 


\title{
A comparison of the pericopes of Joachim Rossihnius and Heinrich Stahl
}

\author{
AHTI LOHK, \\ KRISTIINA ROSS
}

The article compares two Estonian-language translated publications from the early 17th century, the books of pericopes of Joachim Rossihnius (1632) and Heinrich Stahl (1638), to clarify the relationship between them and their connection with a possible earlier tradition. These are two roughly contemporaneous publications, one of which represents South Estonian and the other of which represents North Estonian. Despite the difference in target languages, researchers have previously noticed the great similarity between these two authors' translated texts, which has led to efforts to explain this similarity. The analysis herein aims to contribute to the study of this question, using the historical concordance material of Estonian Bible translations (http://www.eki.ee/piibel/), which allows for easier comparison of different translations. The article presents separate quantitative and qualitative analyses.

For the quantitative analysis, all parts of the Bible occurring in both translations were compared (total 1404 verses) on four levels: the words, their base forms, neighboring words, and word order, using measures of lexical diversity and density, with word pairs identified by Venn diagrams, part of speech filters and symmetrical statistics, cosine similarity and normalized longest common subsequence. The quantitative analysis highlighted the striking similarity between the two translations, which is primarily brought about by the translation method of the time, which emphasized the formal equivalency of the translation with the original. Differences were observed primarily in orthography, which at the time remained highly variable and unstandardized. Interesting differences were also found in the comparison of neighboring words, which confirmed the expectation that e.g. genitive constructions would be formed differently in the two translations. The quantitative analysis also highlighted rarely occurring linguistic forms and particularly weakly connected versions of verses, the further study of which could help to explain the relationship of each translation to previous tradition and the common language of the time.

For the qualitative analysis, roughly half of the material ( 729 chosen verses) was taken and the translations were compared phrase by phrase with each other 
and with their source text, Martin Luther's German translation. The qualitative analysis shows that both versions exhibit examples of a tradition likely dating back to the Catholic period. The coincidence in the usage of terms and formulaic expressions can be explained by these expressions already having taken root. However, within the context of the tradition of the time, the two translations do clearly stand apart from one another: Rossihnius's version preserves greater formal equivalence to the German translation, while Stahl's is more dynamic and contains more vernacular expressions differing from the structure of Luther's version. The rendering of certain individual pericopes can be presumed to have been based on a common earlier translation.

Keywords: history of written Estonian, Bible translation, quantitative textual analysis

Ahti Lohk

Tallinna Tehnikaülikool, tarkvarateaduse instituut

Ehitajate tee 5, 19086 Tallinn

Eesti Keele Instituut, eesti keele ajaloo, murrete ja soome-ugri keelte osakond Roosikrantsi 6, 10119 Tallinn

ahti.lohk@eki.ee

Kristiina Ross

Eesti Keele Instituut, eesti keele ajaloo, murrete ja soome-ugri keelte osakond Roosikrantsi 6, 10119 Tallinn

kristiina.ross@eki.ee 